\title{
A BIPOLARIDADE DO TRABALHO FEMININO NO BRASIL CONTEMPORÂNEO
}

\author{
CRISTINA BRUSCHINI \\ Socióloga, Pesquisadora da Fundação Carlos Chagas \\ MARIA ROSA LOMBARDI \\ Socióloga, Assistente de Pesquisa da Fundação Carlos Chagas
}

RESUMO

Oartigo analisa, com base em múltiplas fontes de dados secundários, a participação das mulheres no mercado de trabalho em dois pólos opostos de atividade. Do primeiro, que abriga as ocupaçôes de má qualidade quanto aos niveis de rendimento, formalização das relações e proteção no trabalho, foi selecionado como objeto de estudo o emprego doméstico. Nos anos 90 , esse segmento manteve algumas das marcas de precariedade que sempre o caracterizaram, como as longas jornadas de trabalho, os baixíssimos níveis de rendimento e de formalização, embora em relação a esses dois últimos aspectos haja alguns sinais promissores de mudanças. Do segundo pólo, composto por "boas" ocupações, caracterizadas por niveis mais elevados de formalização, de rendimentos e de proteção, selecionamos algumas carreiras universitárias, quais sejam, a Engenharia, a Arquitetura, a Medicina e o Direito. Os dados revelaram que as mulheres que ingressaram nessas profissões são mais jovens do que seus colegas. No mais, seu perfil de inserção ocupacional é muito assemelhado ao dos homens, exceção feita aos rendimentos. Seguindo um padrão de gênero encontrado no mercado de trabalho, os ganhos femininos são sempre inferiores aos masculinos.

RELAÇÕESDEGÊNERO - TRABALHO-MULHERES-OCUPAÇÕESPROFISSIONAIS

\section{ABSTRACT}

THE TWO POLES OFWOMEN'S WORK IN CONTEMPORARY BRASIL. Based in multiple sources of secondary data, the article analyzes women's participation in the labor market at two opposite poles of activity. From the first pole, which includes poor quality jobs in terms of income, formalization of relations and protection of work, we selected the position of domestic employees. In the 90s, this segment maintained some of the precarious conditions that have always characterized it, such as a long work day and low levels of income and formalization. There are some promising signs of change with regard to the last two aspects. At the second pole, composed of "good" jobs, characterized by higher levels of formalization, of income and protections, we selected some university careers: Engineering, Architecture, Medicine and Law. The date reveal that women who enter these profession are younger than their colleagues. Otherwise, with the exception of income, their profile of job inclusion is quite similar to men's. According to the gender pattern found in the labormarket, women's earnings are always lower than men's.

Este artigo é uma versão condensada do paper A bipolaridade do trabalho feminino no Brasil: o emprego doméstico e as "novas" ocupações, apresentado no GT Trabalho e Sociedade , XXIII Congresso da Anpocs, Caxambu, Minas Gerais, outubro de 1999 e no IX Congresso Brasileiro de Sociologia da SBS, Porto Alegre, ago.-set. de 1999. 
Estudos anteriores sobre o trabalho feminino e as características da inserção das mulheres no mercado de trabalho brasileiro apontaram uma realidade caracterizada por continuidades e mudanças (Bruschini, 1998b). De um lado, as continuidades dizem respeito ao ainda grande contingente de mulheres (cerca de $40 \%$ da força de trabalho feminina) que se insere no mercado de trabalho em um pólo no qual se incluem as posições menos favoráveis e precárias, quanto ao vínculo de trabalho, à remuneração, à proteção social ou às condições de trabalho propriamente ditas. São ocupações nas quais a presença das mulheres tem se dado tradicionalmente, como o trabalho doméstico, as atividades sem remuneração e as atividades de produção para consumo próprio e do grupo familiar. Inclui-se também, entre as continuidades, o elevado contingente de mulheres em alguns tradicionais nichos femininos, como a Enfermagem e o Magistério, para citar apenas alguns exemplos.

De outro lado, as mudanças apontam na direção de um pólo oposto, no qual ocorre a expansão da ocupação feminina em profissões de nível superior de prestígio, como a Medicina, a Arquitetura, o Direito e mesmo a Engenharia, áreas até há bem pouco tempo reservadas a profissionais do sexo masculino. $\bigcirc$ movimento de ingresso das mulheres nessas áreas científicas e artísticas tem-se dado na esteira dos movimentos políticos e sociais deflagrados nas décadas de 60 e 70 - aqui incluído o movimento feminista - e da mudança de valores culturais deles decorrentes, que se refletiram, entre outras coisas, na expansão da escolaridade das mulheres e, em conseqüência, em seu ingresso maciço no ensino de $3^{\circ}$ grau em uma gama mais ampla de carreiras universitárias.

Trataremos aqui de investigar as características e a dinâmica da inserção feminina em seus dois pólos, ao mesmo tempo complementares e opostos. Para tanto, optamos por selecionar alguns nichos ocupacionais que representam emblematicamente cada uma dessas faces.

Daquela que representa a permanência de padrões femininos tradicionais de inserção selecionamos a categoria trabalhadores domésticos, em razão da sua representatividade na absorção da força de trabalho feminina. Nela se enquadravam, em 1997, nada menos do que $18 \%$ da população feminina economicamente ativa ou aproximadamente 4,8 milhões de mulheres. Do pólo oposto selecionamos algumas carreiras técnicas e científicas que apresentaram expressiva ampliação da presença das mulheres em seus quadros nos últimos 15 anos. São elas a Medicina, a Engenharia, a Arquitetura e o Direito.

A pesquisa de análise de dados secundários foi feita em fontes variadas, selecionadas de acordo com a existência de informações a respeito das ocupações mencionadas. Essa forma mais heterodoxa de conduzir a pesquisa se justificou, neste texto, em virtude de seu principal objetivo: o de desvendar e analisar as mudanças e permanências no lugar ocupado pelas mulheres no mercado de trabalho, mesmo que para isso fosse necessário recorrer a informações de natureza diversificada. Tendo em vista esta preocupação, foi feito utilizando um procedimento metodológico ao qual temos denominado adotar uma pers- 
pectiva de gênero' - verdadeiro garimpo nos dados, em busca de qualquer informação que produzisse maior conhecimento sobre as categorias ocupacionais desejadas.

As fontes de dados utilizadas foram, portanto, tanto os Censos Demográficos e as Pesquisas Nacionais por Amostra de Domicílios - PNADs -, da Fundação Instituto Brasileiro de Geografia e Estatística - FIBGE -, quanto a Relação Anual de Informações Sociais RAIS - do Ministério do Trabalho - MTb, até as últimas datas disponíveis, 1997 no caso da PNAD e 1996 no caso da RAIS, sem evitar a utilização de ambas simultaneamente, sempre com as necessárias ressalvas metodológicas, para a construção de algumas séries históricas. Utilizamos também os recenseamentos demográficos de 1980 e 1991 (e, por vezes, 1970) para descrever e analisar, em profundidade, o emprego doméstico. Ainda o Censo Demográfico, desta vez em seu volume Famílias e Domicílios, forneceu algumas indicações sobre presença e características das empregadas residentes em domićlios particulares urbanos, a partir de dados sobre residentes e sua relação com o chefe de família. As PNADs, por sua vez, a partir de 1992, passaram a oferecer novas possibilidades de analisar o emprego doméstico, razão pela qual também foram utilizadas para o estudo dessa categoria em anos mais recentes, até 1997.

Os indícios para a escolha das carreiras universitárias nas quais a presença das mulheres vem se fazendo sentir de forma mais expressiva, e que se situam no pólo mais desenvolvido, vieram-nos de estudo anterior, que analisou informações dos Censos: Mão-de-Obra de 1980 e 1991 e mostrou aumentos significativos nos percentuais de presença feminina, nesse período, em algumas delas (Bruschini, 1998a). Para analisá-las em maior profundidade e atualidade, optamos por considerá-las em seu segmento formalizado, utilizando informações da RAIS. A análise mais aprofundada da inserção feminina nas carreiras universitárias escolhidas foi realizada em relação a um único ponto no tempo, o mais recente, que foi a RAIS 96.

\section{O PÓLO PRECÁRIO}

\section{Emprego doméstico, profissão feminina}

Dois fatos despertam imediatamente a atenção do analista, ao estudar o emprego doméstico. $\bigcirc$ primeiro deles é a característica essencialmente feminina dessa forma de "atividade econômica, na qual se situam indivíduos que prestam serviços remunerados de natureza não lucrativa a pessoas ou famílias, em suas residências"2. $\bigcirc$ emprego doméstico é um dos maiores guetos femininos, pois trata-se de uma ocupação na qual mais de $90 \%$ dos trabalhadores são mulheres ${ }^{3}$. Esse percentual, como nos revelam os dados da tabe-

I. Para uma discussão sobre a busca de informações orientada por uma pergunta de gênero e para as estratégias mais adequadas para tornar visível o trabalho feminino, ver Bruschini, 1992 e 1998.

2. Definição da profissão, segundo a Lei n. 5.859 de II/I2/1972, que a regulamenta.

3. Por esse motivo usamos neste texto, de preferência, o substantivo no feminino, isto é, empregada doméstica. 
la I, tem declinado ao longo do período considerado, em contrapartida a um ligeiro aumento do percentual masculino, mas a categoria mantém sua marca feminina - em 1970, as mulheres eram maioria absoluta (97,5\%), em 1997 elas são 93\% da categoria.

A natureza feminina do emprego doméstico não é de surpreender. Em nossa sociedade, os afazeres domésticos são tidos como responsabilidade da mulher, qualquer que seja sua situação social, sua posição na família e trabalhe ela ou não fora do lar. Quando esses afazeres são realizados pela dona-de-casa, no âmbito da família, eles não são considerados como trabalho e são computados pelas estatísticas como inatividade econômica. Entretanto, quando as mesmas atividades são realizadas por uma pessoa contratada para esse fim, mediante remuneração em bens ou espécie, elas passam a ser computadas como trabalho, sob o rótulo de serviço ou emprego doméstico. Ou seja, apesar de sua natureza semelhante, as mesmas atividades têm significado diferente para a economia, caso sejam realizadas como prestação de serviços remunerados, ou por alguém da família, em geral uma mulher, sem qualquer pagamento. É por isso que o economista inglês Collin Clark afirmou que, se alguns homens solteiros casassem com suas empregadas domésticas, a renda nacional diminuiria, o inverso ocorrendo se alguns casados se separassem de suas esposas e passassem a pagá-las como domésticas (Bruschini, 1990).

O segundo fato a ser destacado é o peso do emprego doméstico no conjunto da força de trabalho feminina. As trabalhadoras domésticas representavam mais de um quarto da força de trabalho feminina em 1970 (quase 27\%) e, ainda hoje, apesar desse percentual ter sofrido considerável redução, representam cerca de 18\% de todas as trabalhadoras.

Apesar do relativo declínio percentual, o contingente de empregados domésticos, em números absolutos, teve um aumento de mais de 200\% de 1970 a 1997, o que revela a importância que ainda mantém, na economia brasileira, essa forma de atividade econômica. Entre as mulheres, o contingente aumentou de 1,7 milhão para 4,9 milhões de trabalhadoras. Isto quer dizer que essa categoria profissional, formada praticamente só por mulheres, está longe de diminuir no Brasil, ainda que seu peso relativo no conjunto da força de trabalho feminina venha apresentando declínio, provavelmente em virtude do aumento da escolaridade feminina e do surgimento de novas e melhores oportunidades de trabalho para as mulheres mais qualificadas. Por outro lado, o contingente masculino, embora muito pequeno (cerca de 380 mil em 1997), teve um crescimento relativo de cerca de $800 \%$, em relação a 1970.

A importância e o peso do serviço doméstico na atividade econômica das mulheres são, talvez, o melhor exemplo da continuidade que existe neste pólo mais precário de atividade. Desde o século passado, o serviço doméstico vem absorvendo cerca de um quinto das trabalhadoras. Em estudo sobre as ocupações femininas no Brasil, no século XIX, Samara (1997) revela que, das mulheres livres e escravas com profissão registradas pelo Censo de 1872, 22,4\% estavam no serviço doméstico. E, ao contrário do que se poderia 
TABELA I

TRABALHADORES DOMÉSTICOS:

DISTRIBUIÇÃO ENTRE OS OCUPADOS E COMPOSIÇÃO SEGUNDO O SEXO BRASIL - 1970 A 1997

\begin{tabular}{|c|c|c|c|c|}
\hline Anos & & Totais & Homens & Mulheres \\
\hline \multicolumn{5}{|l|}{ 1970* } \\
\hline Ocupados & $(\mathrm{NA})$ & 29.557 .224 & 23.391 .777 & 6.165 .447 \\
\hline Trabalhadores domésticos & & 1.697 .042 & 41.658 & 1.655 .384 \\
\hline Trab. Domésticos/Ocupados & (\%) & 5,7 & 0,2 & 26,8 \\
\hline Composição segundo sexo & & 100 & 2,5 & 97,5 \\
\hline \multicolumn{5}{|l|}{ 1980* } \\
\hline Ocupados & $(\mathrm{NA})$ & 43.235 .712 & 31.392 .986 & I I.842.726 \\
\hline Trabalhadores domésticos & & 2.476 .523 & 108.907 & 2.367 .616 \\
\hline Trab. Domésticos/Ocupados & (\%) & 5,7 & 0,3 & 20 \\
\hline Composição segundo sexo & & 100 & 4,4 & 95,6 \\
\hline \multicolumn{5}{|l|}{1991} \\
\hline Ocupados & $(N A)$ & 55.293 .329 & 37.731 .639 & 17.561 .690 \\
\hline Trabalhadores domésticos & & 3.696 .273 & 271.395 & 3.424 .878 \\
\hline Trab. Domésticos/Ocupados & $(\%)$ & 6,7 & 0,7 & 19,5 \\
\hline Composição segundo sexo & & 100 & 7,3 & 92,7 \\
\hline \multicolumn{5}{|l|}{1995} \\
\hline Ocupados & $(\mathrm{NA})$ & 69.628 .608 & 41.863 .309 & 27.765 .299 \\
\hline Trabalhadores domésticos & & 5.132 .901 & 350.885 & 4.782 .016 \\
\hline Trab. Domésticos/Ocupados & (\%) & 7,4 & 0,8 & 17,2 \\
\hline Composição segundo sexo & & 100 & 6,8 & 93,2 \\
\hline \multicolumn{5}{|l|}{1997} \\
\hline Ocupados & $(\mathrm{NA})$ & 69.331 .507 & 41.977 .258 & 27.354 .249 \\
\hline Trabalhadores domésticos & & 5.242 .846 & 376.931 & 4.865 .915 \\
\hline Trab. Domésticos/Ocupados & (\%) & 7,6 & 0,9 & 17,8 \\
\hline Composição segundo sexo & & 100 & 7,2 & 92,8 \\
\hline
\end{tabular}

Fontes: FIBGE, 1970 (Tab. 16); 1980 (Tab. 1.9); I99 Ib (Tab. 5. 16); 1995a e 1997 (Tab. 4. 19).

* Refere-se à População Economicamente Ativa - PEA. 
supor, a grande maioria delas (83\%) eram brasileiras livres e não escravas, pois estas trabaIhavam sobretudo na lavoura ${ }^{4}$.

Empregadas domésticas: onde estão?

Todas as trabalhadoras domésticas e os poucos trabalhadores domésticos existentes trabalham na prestação de serviços ${ }^{5}$, principalmente como empregadas do setor privado (85\%). Segundo dados do Censo de 1991, apenas 15\% das domésticas trabalhavam por conta própria naquela data, sendo que a grande maioria tinha vínculo como empregada. Como bem lembra Melo (1998), existe, dentro do serviço doméstico remunerado, uma heterogeneidade de situações, que nem sempre são captadas pelos dados. De um lado, as empregadas domésticas que vivem no local de trabalho recebem salário mensal, mais casa e comida: as mensalistas residentes. Há também aquelas que têm contrato mensal, mas que não residem no local de trabalho, embora nele trabalhem diariamente. $\mathrm{Na}$ outra ponta estão as diaristas, que não residem no local de trabalho e trabalham por conta própria em várias casas de família, recebendo por dia, semana ou mês. Qualquer que seja o vínculo de trabalho, uma das características do trabalho doméstico é o local onde é desenvolvida a atividade: a esmagadora maioria (86\%) trabalha no domicílio do patrão ou empregador. Entretanto, cerca de apenas | $8 \%$ delas residem no domicílio da família para a qual trabalham, como foi possível constatar para 1991 (FIBGE, Censo Demográfico: Famílias e Domicílios, 199|). Esse percentual se repete com regularidade impressionante em várias pesquisas, como a de Saffioti (1978), realizada em 1974 na cidade de Araraquara, a de Gogna (1993) realizada em Buenos Aires em 1980, ou o estudo de Graham (1993) para o Rio de Janeiro no final do século XIX, no qual, segundo a autora, pelo menos 17\% das famílias se identificaram, em levantamento de 1870, como tendo empregados que trabalhavam e viviam na casa dos patrões.

$\bigcirc$ quadro I, a seguir, resume as principais características dessas trabalhadoras, assim como dos domićlios nos quais residem e trabalham. As empregadas domésticas residentes (conhecidas, entre nós, como "que dormem no emprego" e na América Latina como "cama adentro") são muito jovens, solteiras, a maioria é preta ou parda. Trabalham em domicílios formados por quatro ou mais pessoas, cujo chefe é do sexo masculino e tem renda e escolaridade de nível médio. Não é difícil imaginar as razões dessas características: as empregadas que moram no emprego são as mais pobres, negras, migrantes, que não dispõem de outra moradia. São também aquelas - jovens e solteiras - que não formaram sua própria família e podem, por isso, se sujeitar às longas jornadas de trabalho e às restri-

4. É provável, entretanto, que um grande contingente de escravas não tenha sido registrado por esse censo, muitas delas criadas de servir "porta adentro", como tão bem relata Matos (1994). Nesse caso o percentual de escravas empregadas domésticas seria bem maior.

5. Dado encontrado na tabela 5. 18, do Censo Demográfico Mão-de-Obra(FIBGE, 199|b). 
ções de sua liberdade de circulação. Os domicílios que as empregam, por sua vez, precisam de seus serviços porque têm mais moradores, mais da metade deles são habitados por famílias em formação, nas quais provavelmente há crianças e adolescentes presentes (famílias cujos chefes têm de 30 a 49 anos) e a grande maioria tem nível de renda médio, podendo arcar com os custos de uma profissional como essa, tempo integral, em seu domicílio.

\section{QUADRO I}

TRABALHADORAS DOMÉSTICAS RESIDENTES NOS DOMICÍLIOS DAS FAMÍLIAS PARA AS QUAIS TRABALHAM: ALGUMAS CARACTERÍSTICAS - BRASIL, I99।

\section{- RESIDENTES/TOTAL DE TRABALHADORAS DOMÉSTICAS EMPREGADAS}

$18,3 \%$

- PERFIL

$96,5 \%$ são do sexo feminino

79,3\% têm até 29 anos, sendo que 43\% delas, até 19

$62 \%$ são pretas e pardas e $36,8 \%$ são brancas

$90 \%$ são solteiras

82,5\% trabalham em domicílios com 4 e mais pessoas

- ALGUMAS CARACTERÍSTICAS DO CHEFE DA FAMÍLIA DO DOMICÍlIO ONDE RESIDEM

$81,3 \%$ são do sexo masculino

$58 \%$ têm entre 30 e 49 anos

$70 \%$ têm 9 anos e mais de estudo

71,4\% têm mais de 5 SM de rendimento médio mensal

Fonte: FIBGE, I 99 Ia (Tabs. 6.6 a 6.10).

Como são as trabalhadoras domésticas?

\section{Mensalistas ou diaristas}

A desagregação interna da categoria, possibilitada somente nos dados censitários, mostra que a grande maioria das trabalhadoras domésticas, assim como dos trabalhadores, são empregados domésticos não especializados, ou seja, realizam todo tipo de atividade na residência para a qual trabalham (Tabela 2), nela residindo ou não. Seguem-lhes, de muito longe, as faxineiras ou diaristas, que trabalham como autônomas. Mantém-se a diferenciação por sexo, exceto no caso da subcategoria "outras ocupações", na qual predominam os homens, supostamente motoristas, jardineiros ou outra forma considerada masculina de atividade doméstica. 
TABELA 2

TRABALHADORES DOMÉSTICOS:

DESAGREGAÇÃO INTERNA E PARTICIPAÇÃO FEMININA

BRASIL - |99|

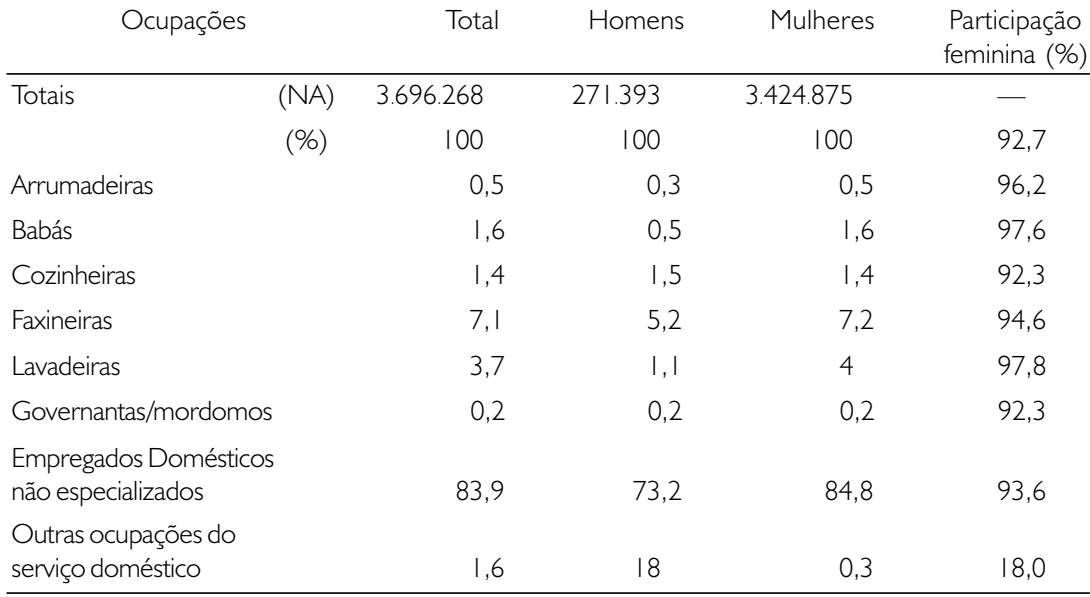

Fonte: FIBGE, I99| (Tab. 5.24).

Melo (1998, Tab.6, p. 334), ao trabalhar com tabulações especiais da PNAD 95, nos permite confirmar essa suposição, ao desagregar essa categoria e revelar que, formada por atendentes de idosos, motoristas e jardineiros, ela ocupa 79\% de homens e apenas $21 \%$ de mulheres. As relações de gênero mantêm-se, portanto, até mesmo no interior de uma ocupação associada a apenas um dos sexos. Ao comparar informações para 1985 e 1995, é ainda Melo quem argumenta que a urbanização e a industrialização poderiam levar à ampliação do número de diaristas, em detrimento do de mensalistas, principalmente residentes, demarcando um louvável processo de profissionalização da categoria. Uma comparação entre nossos dados, para 91, e os analisados por aquela pesquisadora, para 95. (Melo, 1998, Tab. 5, p. 334) mostra que, de fato, ocorre, no período considerado, uma ampliação do peso das diaristas/faxineiras (de 7,2\% para 12\%) no emprego doméstico. Contudo, as domésticas polivalentes continuam sendo maioria, mesmo tendo reduzido seu percentual de 85\% das empregadas em 1991 para 75,6\% em 1995. Liberato (1999), em estudo sobre o serviço doméstico no Brasil no período 1992-1997, também constata que as mensalistas, que trabalham em apenas um domicílio, predominam, com um percentual de $82 \%$, entre as empregadas domésticas. Contrapondo-se à hipótese de extinção dessa modalidade de emprego doméstico, em detrimento de outras como as diaristas, essa autora observa que, entre elas, ocorreu o maior crescimento de postos de trabalho no período analisado, quando foram gerados mais de 516 mil empregos. 
É possível que o processo de urbanização e os novos modos de vida a ele associados - residências menores, trabalho fora de casa das donas-de-casa e mães (Bruschini, 1998b), simplificação do trabalho doméstico, adoção de novas tecnologias domésticas, mesmo que estas não substituam o trabalho da dona-de-casa ou da empregada (Silva, 1998), novos padrões culturais etc. - venham a promover a extinção das residentes, mas não dispomos de dados que permitam comprovar esta hipótese ${ }^{6}$.

\section{Idade e cor/raça}

No primeiro ano do período analisado predominavam, entre as empregadas domésticas, trabalhadoras mais jovens. Em 1991, mais de 58\% tinham menos de 30 anos, $28 \%$ das quais não chegavam nem mesmo aos 20 anos. Não é de estranhar. $O$ emprego doméstico tem sido considerado a porta de entrada no mercado de trabalho para muitas jovens, migrantes das zonas rurais ou de regiões mais pobres do país, que procuram os centros urbanos mais desenvolvidos, nos quais as famílias das camadas médias dispõem de recursos para remunerar esse tipo de ajuda nas tarefas domésticas. Para essas jovens, o emprego doméstico, principalmente quando associado à moradia e à alimentação, é uma estratégia de sobrevivência conveniente logo que chegam na cidade grande, mas, na medida do possível, é provisória. As que têm algum estudo logo procuram ir para outra atividade mais bem remunerada, ou de maior prestígio, ou na qual disponham de maior liberdade de horário e de moradia, especialmente quando se casam e constituem família. De fato, foi possível constatar em nossos dados que vem ocorrendo um relativo envelhecimento dessas trabalhadoras. Em 1997, mais da metade delas (53,7\%) tem mais de 30 anos, o que representa uma inversão em relação aos anos anteriores, nos quais mais da metade era mais jovem, com menos de 30 anos (58\% em 1991, 51,4\% em 1995). Esse relativo envelhecimento da categoria pode estar sendo provocado pelo deslocamento das mais jovens, provavelmente mais escolarizadas, para outras ocupações. É preciso destacar, contudo, que o percentual das muito jovens, com menos de 20 anos, ainda é elevado em 1997 (20\%), mesmo tendo diminuído na década.

O predomínio das muito jovens se intensifica ao se examinar a associação do emprego doméstico com a cor/raça da trabalhadora. No Brasil, conforme mostra a tabela 4, as pretas e pardas predominam (59\%) nessa categoria ocupacional, seguidas das brancas (41\%). Além disso, as negras e pardas, em 1991, eram mais jovens do que as brancas: respectivamente, $60 \%$ e $56 \%$ tinham até 29 anos naquela data.

O padrão etário de participação das empregadas domésticas repete-se, com algumas diferenças, em algumas regiões metropolitanas. Os principais destaques ficam por

6. Recentemente, ao visitar inúmeros apartamentos de classe média para jovens casais e surpreender-me com a nova denominação - espaço multiuso - do quarto de empregada, fui informada pela corretora que "os casais, hoje em dia, não querem mais empregada que dorme no emprego, porque os dois trabalham fora, porque tira a liberdade etc., por isso o antigo quarto, se desejado, pode ser usado para outra finalidade". 
TABELA 3

TRABALHADORAS DOMÉSTICAS POR FAIXAS DE IDADE BRASIL - 199I, I995 E 1997

\begin{tabular}{lrrrr}
\multicolumn{1}{c}{ Faixas de idade } & 1991 & 1995 & 1997 \\
\hline Total & (NA) & 3.424 .878 & 4.782 .016 & 4.865 .915 \\
& $\%$ & 100,0 & 100,0 & 100,0 \\
Até 19 anos & 28,0 & 23,5 & 20,1 \\
De 20 a 29 anos & 30,1 & 27,9 & 26,6 \\
De 30 a 49 anos & 33,3 & 38,5 & 42,9 \\
50 anos e mais & 8,6 & 10,1 & 10,8 \\
\hline
\end{tabular}

Fonte: FIBGE, I99I (Tab. 5.37); 1995a e 1997a (Tab. 4.19).

TABELA 4

TRABALHADORAS DOMÉSTICAS SEGUNDO COR/RAÇA E IDADE BRASIL - 199।

\begin{tabular}{|c|c|c|c|c|c|}
\hline \multirow{2}{*}{\multicolumn{2}{|c|}{ Faixas de idade e cor/raça }} & \multicolumn{4}{|c|}{ Cor/raça } \\
\hline & & Total & Branca & Preta ou Parda & Outras \\
\hline \multirow[t]{2}{*}{ Total } & $(\mathrm{NA})$ & 3.424 .878 & 1.395 .612 & 2.012 .876 & 6.225 \\
\hline & (\%) & 100 & 40,7 & 58,8 & 0,2 \\
\hline \multicolumn{6}{|c|}{ Distribuição por idade } \\
\hline \multicolumn{2}{|c|}{ Até 19 anos } & 28 & 25,9 & 29,3 & 20,9 \\
\hline \multicolumn{2}{|c|}{ De 20 a 29 anos } & 30,1 & 29,8 & 30,3 & 24,3 \\
\hline \multicolumn{2}{|c|}{ De 30 a 49 anos } & 33,3 & 35,1 & 32,1 & 41 \\
\hline \multicolumn{2}{|c|}{50 anos e mais } & 8,6 & 9,2 & 8,3 & 13,8 \\
\hline \multicolumn{2}{|l|}{ Total } & 100 & 100 & 100 & 100 \\
\hline
\end{tabular}

Fonte: FIBGE, I99I(Tab. 5.37).

Obs.: Exclusive "sem declaração". 
conta de São Paulo, Rio de Janeiro e Porto Alegre, cidades nas quais as empregadas são mais velhas, e Fortaleza, onde elas são mais jovens do que o padrão nacional. Essas diferenças poderiam ser atribuídas a distintos padrões de desenvolvimento urbano que, ao propiciar melhor atendimento escolar e melhores oportunidades de emprego nas regiões mais desenvolvidas, estaria favorecendo o deslocamento das mais jovens e mais qualificadas para outras ocupações no comércio ou na prestação de serviços, como balconistas, enfermeiras, escriturárias, costureiras ou cabeleireiras, como também lembra Saffioti (1978). Talvez por não dispor das mesmas condições, Fortaleza mantenha o padrão etário nacional do emprego doméstico de 1991, com 58\% das trabalhadoras dessa categoria com menos de 30 anos (Tabela 5).

Esta hipótese pode ser confirmada por meio de dados de Melo (1998, Tab. I5, p. 345) referentes à escolaridade das empregadas domésticas, segundo os quais é no Nordeste que se verificam os percentuais mais elevados de analfabetismo e baixa escolaridade no emprego doméstico. No Brasil, em 1995, 15,5\% das empregadas eram analfabetas e $73 \%$ tinham apenas o $1^{\circ}$ grau incompleto. Mas no Nordeste o analfabetismo dessa categoria atingia $23,6 \%$ e o $1^{\circ}$ grau incompleto era de $69,5 \%$, inferior ao verificado nas demais regiões do país. Vale ressaltar, contudo, que essa mesma autora constata um aumento da escolaridade nessa categoria, entre 1985 e 1995.

TABELA 5

TRABALHADORAS DOMÉSTICAS SEGUNDO FAIXAS DE IDADE BRASIL E REGIÕES METROPOLITANAS - 1995

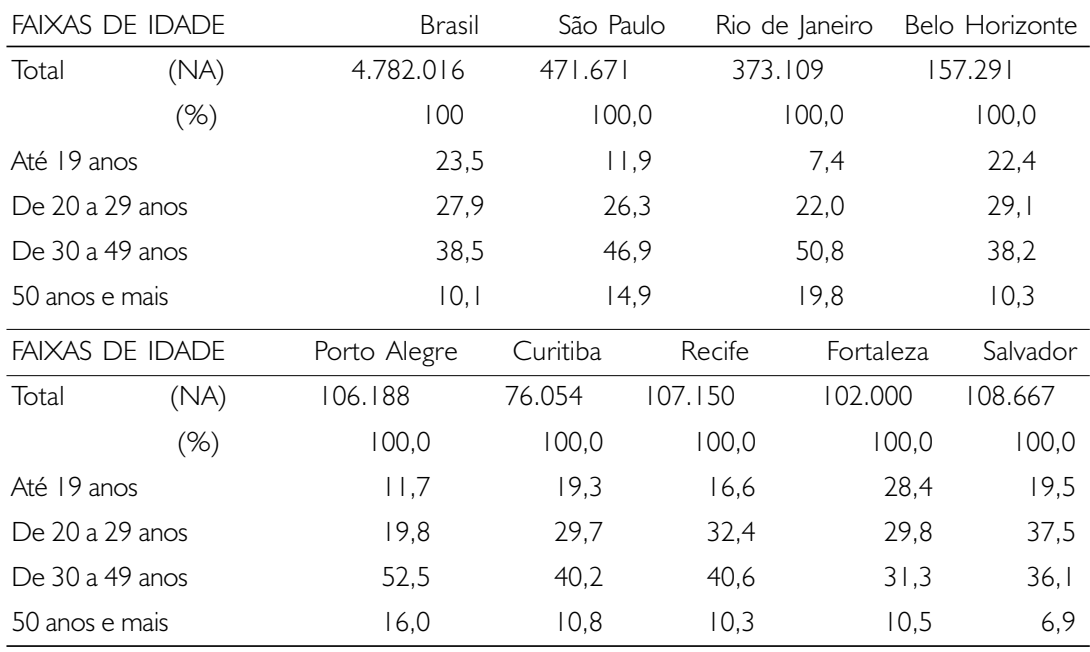

Fonte: FIBGE, 1995a (Tab. 4.19). 


\section{Jornada de trabalho e legislação}

O emprego doméstico é uma das ocupações mais precárias que existem no mercado de trabalho. Alguns indicadores, como a jornada de trabalho, a posse de carteira assinada e o nível de rendimentos são utilizados, neste texto, para comprovar a má qualidade dessa ocupação. As empregadas domésticas trabalham uma longa jornada, superior àquela que é prevista na legislação para os demais trabalhadores. Os dados apresentados na tabela 6 revelam que, em 1991, mais de 76\% delas declaravam ter uma jornada de trabalho superior a 40 horas e $41 \%$ delas de mais de 45 horas. Um olhar mais detido sobre a categoria, desagregada por especialidade, sugere que apenas as diaristas, faxineiras e lavadeiras conseguem manter sua jornada em limites mais razoáveis. Para todas as demais, a jornada semanal se prolonga excessivamente, estendendo-se para além das 45 horas.

Ao longo do tempo, como é possível constatar pelos dados a seguir, houve uma relativa redução da jornada de trabalho dessa categoria profissional, dada a diminuição do percentual de empregadas que trabalham mais do que 45 horas semanais ${ }^{7}$.

A delimitação da jornada de trabalho de 44 horas semanais, segundo as mesmas regras estabelecidas para todos os trabalhadores, tem sido uma demanda constante das associações e dos sindicatos dessa categoria, excluída, em 1943, da Consolidação das Leis do Trabalho - CLT -, conforme se constata em seu artigo $7^{\circ}$. A regulamentação da prestação de serviços domésticos tem sido relegada a segundo plano pelos legisladores, tanto em função da natureza íntima das relações que se estabelecem entre empregado e empregador - assim como com os demais membros da família - quanto pelo fato de não configurar, nessa relação, o típico conflito entre capital e trabalho, uma vez que o produto gerado, bens ou serviços, é consumido pela própria família e, portanto, não gera lucro. A incorporação dos empregados domésticos à CLT implicaria considerar a família como uma empresa, quando as atividades que têm lugar na família em nada se assemelham às que ocorrem em uma empresa quanto ao destino dos bens e serviços em ambas produzidos (Saffioti, 1978).

Excluída da CLT em 1943, a profissão, décadas mais tarde, foi regulamentada pela Lei n. 5.859, de II/I2/1972, sendo considerado como empregado doméstico "aquele que presta serviços de natureza contínua e de finalidade não-lucrativa à pessoa ou à família, no âmbito residencial desta", definição que excluía os que trabalhavam em caráter eventual, como as faxineiras. Essa lei foi regulamentada pelo Decreto n. 71.885, de 9/3/73, e

7. Cabem aqui, no entanto, duas importantes ressalvas de ordem metodológica. Em primeiro lugar, a comparação entre fontes diferentes - Censo em I99 I e PNAD em 1995 e 1997 - pode estar influenciando esse movimento. Em segundo, o fato de que, como os dados de 1995 e 1997 não são desagregados por sexo, para essa varíável, tomou-se a liberdade de computar os totais de homens e mulheres, considerando a esmagadora maioria dessas últimas na categoria (mais de 90\%, cf. Tab. I). 
TABELA 6

TRABALHADORAS DOMÉSTICAS SEGUNDO HORAS SEMANAIS TRABALHADAS BRASIL - 1991

\begin{tabular}{|c|c|c|c|c|c|c|}
\hline Ocupações & $\begin{array}{l}\text { Totais } \\
\text { NA }\end{array}$ & $\begin{array}{c}\text { Até } 14 \text { hs } \\
\%\end{array}$ & $\begin{array}{c}15 \text { a } 29 \mathrm{hs} \\
\%\end{array}$ & $\begin{array}{c}30 \text { a } 39 h s \\
\%\end{array}$ & $\begin{array}{c}40 \text { a } 44 \text { hs } \\
\%\end{array}$ & $\begin{array}{c}45 \mathrm{hs} \text { e mais } \\
\%\end{array}$ \\
\hline Totais & 3.424 .875 & 2,7 & 10,1 & 10,9 & 35,3 & 41,0 \\
\hline Arrumadeiras & 17.525 & 3,0 & 8,6 & $\mid 1,1$ & 35,6 & 41,7 \\
\hline Babás & 56.161 & 1,6 & 12,2 & 13,0 & 32,4 & 40,7 \\
\hline Cozinheiras & 48.673 & 2,2 & 7,2 & 10,1 & 33,8 & 46,7 \\
\hline Faxineiras & 247.558 & 8,1 & 26,3 & 15,7 & 30,3 & 19,5 \\
\hline Lavadeiras & 135.305 & 15,7 & 33,0 & 16,4 & 19,1 & 15,7 \\
\hline $\begin{array}{l}\text { Governanta/ } \\
\text { mordomo }\end{array}$ & 6.072 & 1,4 & 6,1 & 10,9 & 32,6 & 49,0 \\
\hline $\begin{array}{l}\text { Empregado doméstico } \\
\text { não especializado }\end{array}$ & 2.902 .829 & ।,7 & 7,6 & 10,2 & 36,6 & 43,9 \\
\hline $\begin{array}{l}\text { Outras ocupações do } \\
\text { serviço doméstico }\end{array}$ & 10.752 & 2,8 & 9,5 & 11,4 & 28,0 & 48,3 \\
\hline
\end{tabular}

Fonte: FIBGE, 199| (Tab. 5.19).

TABELA 7

TRABALHADORAS DOMÉSTICAS SEGUNDO HORAS SEMANAIS TRABALHADAS BRASIL - 199I, I995 E 1997

\begin{tabular}{|c|c|c|c|c|}
\hline \multicolumn{2}{|c|}{ Horas Trabalhadas } & |99| & 1995 & 1997 \\
\hline Total & $(\mathrm{NA})$ & 3.424 .878 & 5.132 .901 & 5.242 .846 \\
\hline & $\%$ & 100,0 & 100,0 & 100,0 \\
\hline Até 14 & & 27,0 & 6,1 & 7,1 \\
\hline De 15 a 39 & & 21,0 & 25,1 & 24,7 \\
\hline De 40 a 44 & & 35,3 & 20,8 & 21,4 \\
\hline De 45 a 48 & & $41,0 *$ & $|8|$, & 19,2 \\
\hline 49 ou mais & & - & 29,8 & 27,6 \\
\hline
\end{tabular}

Fonte: FIBGE, I99I (Tab. 5.19); I995a e 1997a (Tab. 4.24).

* 45 e mais.

** Dados não desagregados por sexo. 
garantia aos empregados domésticos: férias remuneradas (20 dias) após 12 meses ininterruptos de prestação de serviços a um mesmo empregador; qualidade de segurado obrigatório da previdência social, garantindo-lhe, portanto, os benefícios da Previdência. Além disso, tornava obrigatório o registro na carteira de trabalho, na qual o empregador tem o dever de registrar as datas de admissão, início e término de férias, dispensa e salário mensal ajustado.

Anos mais tarde, a Constituição de 1988, como consta em seu artigo $7^{\circ}$, parágrafo único, passa a assegurar às trabalhadoras domésticas os seguintes direitos: salário mínimo; não redução do salário (irredutibilidade de salário); $13^{\circ}$ salário; repouso semanal remunerado, de preferência aos domingos; férias anuais remuneradas com, pelo menos, um terço a mais do que o salário normal; licença-gestante, com duração de 120 dias, paga diretamente pelo INSS; aviso prévio; vale-transporte; inscrição na Previdência Social. Entretanto, não são assegurados, a essa categoria, o Fundo de Garantia por Tempo de Serviço FGTS - e a delimitação da jornada de trabalho (CFEMEA, 1994).

Um projeto de lei que concede às empregadas domésticas esses e outros benefícios, como o seguro-desemprego, e, em contrapartida, permite que o empregador desconte gastos com alimentação e moradia, encontra-se em tramitação no Congresso Nacional desde 1989. No entanto, há muita controvérsia sobre o tema. Argumenta-se, novamente, que o trabalho realizado pelas empregadas domésticas difere daquele realizado por outros trabalhadores, na medida em que não configura uma relação capital-trabaIho típica: não gera lucro para a família na qual ela trabalha e esta, por sua vez, não é uma microempresa. Quanto à jornada, os afazeres domésticos - tanto para a empregada quanto para a dona-de-casa - não estão sujeitos, como em uma fábrica ou escritório, a ritmos ou tempos delimitados. Além disso, dificilmente haverá supervisão ou controle no espaço familiar, onde o trabalho é realizado. A questão é mais complexa quando se trata de empregadas residentes, sujeitas à constante solicitação por parte dos moradores do domićlio e, portanto, a jornadas mais longas. Para as mensalistas não residentes e, principalmente, para as diaristas, a delimitação da jornada parece ser mais viável, em virtude da separação entre o local de trabalho e o de moradia. De fato, como vimos anteriormente, faxineiras e lavadeiras trabalham um número significativamente menor de horas do que as domésticas não especializadas, as cozinheiras e demais profissionais da categoria.

De qualquer forma, o importante a considerar é que, antes da Lei n. 5.859, de 1972, as empregadas domésticas não tinham nenhum direito assegurado. Em 1972 passam a ter direito à carteira assinada, assistência médica pelo INSS, aposentadoria e férias de 20 dias, direitos esses que foram ampliados pela Constituição de 1988, o que pode sinali-

8. A partir de março do ano 2000 o empregado doméstico passa a ter acesso, em caráter facultativo, ao regime do FGTS e ao programa do seguro-desemprego (Legislação Trabalhista e Previdenciária, IOB, ano XXIV - $4^{\mathrm{a}}$ semana - fevereiro de $2000-$ n. 8, p. I). 
zar alguma melhora. No entanto, é preciso lembrar que somente aquelas com carteira de trabalho assinada pelo empregador têm esses direitos. Mas essas, como veremos a seguir, são minoria.

\section{Registro em carteira}

Não chega a um quarto das trabalhadoras domésticas o número das registradas, embora se possa assinalar, ao longo do período analisado, um movimento promissor, no sentido de ampliação deste percentual. Mesmo assim, na última data analisada, quase no final do século $X X$, ainda é de apenas $21,6 \%$ o percentual de registro na categoria, o que reitera a precariedade dessa ocupação.

\section{TABELA 8}

TRABALHADORAS DOMÉSTICAS SEGUNDO POSSE

DE CARTEIRA DE TRABALHO ASSINADA BRASIL - 199I, I995 E 1997

\begin{tabular}{ccc} 
Ano & Total & \% com Carteira Assinada \\
\hline 1991 & 3.424 .878 & 21,3 \\
1995 & 4.782 .016 & 17,8 \\
1997 & 4.865 .915 & 21,6 \\
\hline
\end{tabular}

Fonte: FIBGE, I99I (Tab. 5.37), 1995a e 1997a (Tab. 4.21).

Obs.: Exclusive "sem declaração".

Retomando a questão da discriminação racial, verifica-se que as empregadas domésticas pretas e pardas, que constituem maioria na categoria, são as que têm índices mais baixos de registro em carteira - 19\%, em comparação a $24,4 \%$ das brancas - como se constata pelos dados da tabela seguinte.

\section{TABELA 9}

TRABALHADORAS DOMÉSTICAS, COR/RAÇA E POSSE DE CARTEIRA ASSINADA - BRASIL - 199I

\begin{tabular}{lcc} 
Cor/raça & Total & Com carteira assinada \\
& NA & 21,3 \\
\hline Total & 3.424 .878 & 24,4 \\
Brancas & 1.395 .612 & 19,1 \\
Pretas e pardas & 2.012 .876 & 25,5 \\
Outras & 6.225 & \\
\hline
\end{tabular}

Fonte: FIBGE, I99। (Tab. 5.37).

Obs.: Exclusive "sem declaração". 
Levando em consideração diferenças regionais, a desigualdade fica bastante evidente. Comparem-se, por exemplo, os índices bem mais elevados de registro profissional em Porto Alegre e Belo Horizonte (respectivamente 40\% e 33\%), São Paulo e Rio de Janeiro (em torno de 24\%), com o baixíssimo percentual observado em Fortaleza, cidade em que apenas 4,4\% das trabalhadoras domésticas têm carteira de trabalho assinada.

TABELA 10

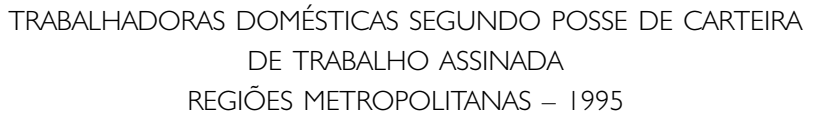

\begin{tabular}{|c|c|c|c|c|c|}
\hline Posse de carteira de trabalho & Brasil & São Paulo & \multicolumn{2}{|c|}{ Rio de Janeiro } & Belo Horizonte \\
\hline Total $\quad(N A)$ & 4.782 .016 & $47|.67|$ & 373.1 & & 7.537 \\
\hline (\%) & 100 & 100,0 & & 0,0 & 100,0 \\
\hline Com carteira assinada & 17,8 & 24,5 & & 4,6 & 32,8 \\
\hline Sem carteira assinada & 82,2 & 75,5 & & 5,4 & 67,2 \\
\hline Posse de carteira de trabalho & Porto Alegre & Curitiba & Recife & Fortaleza & Salvador \\
\hline$(\mathrm{NA})$ & 106.188 & 76.054 & 107.150 & 102.000 & 108.667 \\
\hline (\%) & 100,0 & 100,0 & 100,0 & 100,0 & 100,0 \\
\hline Com carteira assinada & 39,8 & 21,2 & 21,9 & 4,4 & 22,4 \\
\hline Sem carteira assinada & 60,2 & 78,8 & 78,1 & 95,6 & 77,6 \\
\hline
\end{tabular}

Fonte: FIBGE, 1995a (Tab. 4.21).

O registro em carteira é o instrumento legal de que dispõe a trabalhadora doméstica, assim como os demais trabalhadores do país, para ter acesso aos direitos trabalhistas e constitucionais. Mas é também um incentivo para a maior permanência no emprego. Enquanto as registradas permaneciam, em 1995, mais de dois anos e até mesmo mais de cinco anos no emprego, as que não tinham registro apresentavam índices de rotatividade muito maior; mais de um quarto não permanecia sequer cinco meses no emprego ${ }^{9}$. Ou seja, o registro beneficia também os empregadores, na medida em que propicia redução de rotatividade da empregada. No entanto, a rotatividade no emprego doméstico depende também de outros fatores, como mostram pesquisas qualitativas. Saffiotti (1978) e Gogna (1993), por exemplo, observaram que o emprego doméstico é uma ocupação com alta mobilidade e rotatividade. A mobilidade horizontal caracteriza o trânsito dos indivíduos pela ocupação. Como praticamente não há mobilidade vertical ou ascendente, a carreira profissional consiste em mudanças para outros empregos nos quais os problemas básicos - salário, bom ambiente, sentir-se bem com a família, horário, carga de trabalho etc. - sejam mais bem resolvidos.

9. Segundo dados apresentados na versão integral deste texto. 


\section{Rendimentos}

Uma das características do emprego doméstico é o baixo nível dos rendimentos auferidos. No Brasil, em 1991, a grande maioria da categoria (72,5\%) recebia até um salário mínimo por seu trabalho (Tabela I I). Repete-se, no interior da categoria, a já conhecida desigualdade de gênero. Mesmo sendo minoria, os empregados domésticos ganham mais do que as empregadas. Em 1995, 20,5\% deles e apenas 9,5\% delas recebiam mais do que dois salários mínimos por seu trabalho. Embora mantendo níveis salariais bastante baixos, os rendimentos das empregadas domésticas, ao longo da década, vêm tendo uma relativa melhora, principalmente se for levada em conta a redução do percentual das que ganham menos do que o mínimo legal. Nas faixas mais elevadas (dois a três e mais de três salários mínimos) pode ser observada também uma significativa melhora.

TABELA I I

TRABALHADORES DOMÉSTICOS SEGUNDO O SEXO E FAIXAS DE RENDIMENTO BRASIL - 199I, 1995 E 1997

\begin{tabular}{lccc} 
Sexo e faixas de rendimento & $|99|$ & 1995 & 1997 \\
\hline Homens & 100 & 100 & 100 \\
Até I/2 SM* & 15,4 & 13,6 & 8,8 \\
Mais de I/2 a I SM & 35,6 & 37,7 & 33,3 \\
Mais de I a 2 SM & 30,7 & 28,2 & 31,5 \\
Mais de 2 a 3 SM & 9,2 & 10,7 & 15,7 \\
Mais de 3 SM & 6,6 & 9,8 & 10,7 \\
Mulheres & 100 & 100 & 100 \\
Até I/2 SM* & 31,7 & 19,1 & 16,5 \\
Mais de I/2 a I SM & 40,8 & 47,1 & 44,1 \\
Mais de I a 2 SM & 20,6 & 24,3 & 26 \\
Mais de 2 a 3 SM & 4,6 & 6,1 & 9,1 \\
Mais de 3 SM & 2,2 & 3,4 & 4,3 \\
\hline
\end{tabular}

Fonte: FIBGE, I 99 Ib (Tab. 5.24); PNADs 1995 e 1997 (Tab. 4.22).

* Salários mínimos.

Obs.: Exclusive "sem declaração".

Outros trabalhos recentes, como o de Melo (1998) para o período I 985-1995 e o de Liberato (1999), para os anos 1992-1997, chegam a conclusão semelhante. Segundo a última autora, que fez uso de índices de precariedade para a análise de rendimentos, houve nítida melhora no período 1992 a 1997, no qual as domésticas tiveram um ganho de mais de 43\% em seus rendimentos. Em 1997, 91\% delas ganham, pelo menos, um salário mínimo. É inegável que esse aumento está relacionado à ampliação do registro em carteira, 
vista anteriormente neste texto, pois, segundo a Constituição de 1988, o registro é atrelado ao pagamento de um salário mínimo. Mas um e outro continuam sendo direitos aos quais nem todas as empregadas domésticas conseguiram ter acesso. Pois, segundo nossos dados, em 1997, 16,5\% das domésticas brasileiras ainda ganhavam apenas meio salário por seu trabalho.

A maior especialização, dentro da categoria, favorece ganhos um pouco melhores como os das cozinheiras e babás e, mais ainda o das governantas, as quais, no entanto, têm peso pouco importante na categoria. De acordo com Liberato (1999), as empregadas que ganham menos são as que trabalham sem carteira em um único domicílio. No entanto, elas não aumentaram no período por ela analisado. As diaristas foram as que apresentaram as maiores elevações de renda no período e são as que menos têm carteira. $\bigcirc$ segmento que mais cresceu em números absolutos - as mensalistas com carteira - foi o que teve o menor ganho salarial de toda a categoria, provavelmente porque os aumentos apenas acompanharam as variações no valor nominal do salário mínimo. A autora atribui o crescimento do número de mensalistas com carteira, apesar do menor ganho salarial, a uma preferência das mulheres por uma ocupação formal, tendo em vista maior segurança no emprego. Esquece-se, no entanto, de mencionar alguns outros fatores, como a renda não monetária advinda da economia de gastos com moradia, alimentação e outros itens, como é descrito em pesquisas sobre o tema. Saffioti ( 1978) menciona os presentes, como roupas e remédios que, embora revelem o caráter paternalista da relação patroa-empregada, não deixam de configurar um ganho indireto da empregada. Brites (1997) analisa a circulação de objetos entre patrões e empregadas e comenta que quase tudo que as empregadas têm em suas casas, que foram por ela visitadas, veio da residência de alguma patroa. Segundo essa pesquisadora, os donativos em espécie compensam os baixos salários e, mais do que um salário indireto, constituem uma transmissão de patrimônio, repleta de significados sociais. Os pequenos roubos de objetos pessoais também são mencionados em seu estudo, assim como no de Almeida ( 1982), sobre os conflitos e tensões que se estabelecem na relação patroa-empregada.

Mas é preciso lembrar ainda os ganhos efetivamente obtidos pelo registro em carteira, como férias de 30 dias, mais um terço do salário, $13^{\circ}$ salário, aviso prévio e outros ganhos na eventualidade de uma dispensa sem justa causa. Vale mencionar, finalmente, a prática usual, em geral acordada entre ambas as partes, de pagar à empregada doméstica, por fora, um salário superior ao registrado na carteira. Essa prática, sobre a qual não há dados, parece crescer na medida em que o registro implica despesas adicionais para o empregador, mas também para a empregada, sem a adequada contrapartida dos serviços públicos.

Em suma, a análise do emprego doméstico revela a permanência de um nicho ocupacional que continua tendo peso significativo na força de trabalho feminina. Apesar das mudanças, a ocupação emprega 17\% da mão-de-obra feminina no Brasil e continua, em 
números absolutos, em ascensão. Contudo, não obstante esse aparente imobilismo, a categoria vem tendo maior acesso a direitos trabalhistas e sociais, sobretudo nos centros urbanos mais desenvolvidos, por meio de maior índice de registro em carteira, e significativos aumentos salariais, parecendo caminhar para maior profissionalização.

\section{O PÓLO MAIS DESENVOLVIDO'0}

Ao lado das continuidades que vêm caracterizando a inserção das mulheres na estrutura ocupacional brasileira, vem ocorrendo também um movimento consistente de ingresso em nichos ocupacionais de maior prestígio, caracterizados pela presença de profissionais de nível universitário. É o caso das ocupações técnicas, científicas, artísticas e assemelhadas. Essas ocupações sempre representaram um nicho importante de colocação da mulher no mercado de trabalho. Segundo o Censo de 1991, 16\% das ocupadas (ou cerca de 2,8 milhões) desempenhavam funções assim caracterizadas. Para aquilatar a importância desse grupo de ocupações deve-se ter em mente que ele se situa em terceiro lugar entre os grupos de ocupações nos quais a presença feminina é mais significativa. Precedem-lhe, por ordem de importância, aqueles nos quais a presença das mulheres já é bastante tradicional: as ocupações da prestação de serviços e da área administrativa, que absorvem, respectivamente, $29,8 \%$ e 16,8\% da força de trabalho feminina.

É bem verdade que na expressiva proporção de mulheres que desempenham ocupações técnicas, científicas e assemelhadas têm peso especial aquelas que desenvolvem ainda ocupações tradicionais femininas, como as docentes e as que desempenham atividades auxiliares do ensino (elas representam 60\% das ocupadas daquele grupo) e as mulheres que têm funções auxiliares da Medicina e Odontologia (outros 15\%). Nesta última categoria se incluem as enfermeiras, as técnicas em enfermagem, as nutricionistas. Entretanto, quando se comparam os dados de 1991 com os do Censo de 1980, podem ser verificadas algumas alterações importantes na participação feminina nos demais subgrupos de ocupações técnicas e científicas (Bruschini, 1998a): na década de 80 ocorreram tanto a ratificação de tendências que apontavam para um processo de feminização de certas profissões, quanto movimentos pioneiros de avanço da participação da mulher em ocupações cuja tônica, até então, era a predominância de homens.

A carreira de dentista, por exemplo, já apresentava, no início do período, tendência a maior feminização quando comparada com a Medicina. Esse quadro acaba ficando mais evidente em 1991: neste ano nada menos do que 42\% dos dentistas e um terço dos médicos eram do sexo feminino. A mesma tendência parece se consolidar para a Engenharia e a Arquitetura. A primeira especialidade ainda apresenta restrições ao ingresso das

10. Uma versão condensada deste tópico será publicada (prelo), sob a forma de artigo na Revista Estudos Feministas com o título "Médicas, Arquitetas, Advogadas e Engenheiras: mulheres em carreiras de prestígio". 
mulheres (em 1991 as engenheiras somavam apenas 6,6\%), enquanto a Arquitetura tem sido mais receptiva ao ingresso das mulheres e apresentado grande expansão: em 1980, um pouco mais de um terço dos arquitetos eram mulheres, cifra que alcança quase a metade desse grupo em 1991.

Mas é no seio das ocupações jurídicas de nível superior que ocorreram transformações que merecem ser especialmente remarcadas: o ingresso importante das mulheres nas carreiras de juízes e procuradores, promotores e curadores públicos. As juízas, por exemplo, que não passavam de $8 \%$ do conjunto em 1980, chegam aos 20\% em 1991. O mesmo movimento se observa entre procuradores, promotores e curadores públicos: de 20\% em 1980, as mulheres saltam para 36\% em 1991.

Com base nesses indícios, selecionamos para aprofundamento, neste estudo, quatro carreiras profissionais: a Engenharia, a Arquitetura, a Medicina e o Direito" .

Características e dinâmica da inserção feminina na Engenharia, Arquitetura, Medicina e Direito

A primeira observação que deve ser feita, especificamente em relação a essas carreiras, é a consolidação da presença feminina entre esses profissionais, única exceção feita aos engenheiros, no período 1990 a 1996, segundo análise na qual nos baseamos em dados da RAIS, do Ministério do Trabalho'2.

Nessa categoria, a participação do sexo feminino atingia 12\% no conjunto de todas as engenharias em 1996, não tendo se alterado significativamente na década, pois em 1990, apenas I I\% eram do sexo feminino (Tabela 12). Entre os arquitetos, a fatia feminina é bem mais substantiva: em 1996, 54\% dos arquitetos eram mulheres, dados que consolidam a tendência de feminização da profissão, que vem sendo sinalizada há, pelo menos, duas décadas. A mesma tabela mostra que também entre os médicos, a progressão se confirmou: em 1996, 38\% eram mulheres e em 1990, 31,5\%.

O grupo de ocupações advogados, procuradores, juízes, promotores e consultores jurídicos, por sua vez, também presenciou um incremento significativo de mulheres: no

1।. Gostaríamos de ressalvar aqui a colaboração que recebemos de Dinaura Paulino Franco, bibliotecária do Conselho Regional de Medicina - CRM/SP -, Secção São Paulo, da Drª Adriana Gragnani, da Comissão da Mulher Advogada da Ordem dos Advogados do Brasil - OAB/SP -, Seccional São Paulo e da arquiteta Célia Ballario, coordenadora do GT Mulher no Mercado de Trabalho, do Conselho Regional de Engenharia, Arquitetura e Agronomia do Estado de São Paulo - CREA/SP -, na etapa de levantamento bibliográfico e de eventuais pesquisas sobre as profissões aqui enfocadas.

12. Relembre-se aqui que a abrangência da RAIS se refere ao universo do emprego formal. Deve-se considerar, entretanto, que médicos, engenheiros, arquitetos e advogados tendem a estar expostos a relações de trabalho menos formalizadas até em razão das características do próprio trabalho. Em alguns casos, seus serviços são requisitados pontualmente e podem ter caráter sazonal, depender das flutuações da demanda ou de outros eventos que solicitem sua intervenção profissional. Essa parcela de profissionais que não mantém vínculo formal com nenhum tipo de instituição ou empresa não é coberta pela fonte de dados citada. 
TABELA 12

PARTICIPAÇÃO FEMININA EM OCUPAÇÕES SELECIONADAS BRASIL - 1990, 1993 E 1996

\begin{tabular}{|c|c|c|c|c|c|c|}
\hline \multirow[b]{2}{*}{ Ocupações } & \multicolumn{2}{|c|}{1990} & \multicolumn{2}{|c|}{1993} & \multicolumn{2}{|c|}{1996} \\
\hline & Total & $\begin{array}{l}\% \text { de } \\
\text { mulheres }\end{array}$ & Total & $\begin{array}{c}\% \text { de } \\
\text { mulheres }\end{array}$ & Total & $\begin{array}{c}\% \text { de } \\
\text { mulheres }\end{array}$ \\
\hline Médicos & 151.653 & 31,5 & | 35.089 & 36,3 & | 45.45| & 37,9 \\
\hline $\begin{array}{l}\text { Advogados, procurad } \\
\text { juízes promotores e } \\
\text { consultores jurídicos }\end{array}$ & 42.362 & 31,4 & 42.730 & 32,9 & 44.038 & 35,9 \\
\hline Advogados & 25.957 & 32,8 & 24.729 & 35,1 & 23.121 & 38,8 \\
\hline $\begin{array}{l}\text { Procuradores e } \\
\text { consultores jurídicos }\end{array}$ & 8.467 & 38,0 & 7.183 & 40,6 & 9.115 & 42,0 \\
\hline Juízes e promotores & 7.938 & 19,8 & 10.818 & 22,5 & 11.802 & 25,5 \\
\hline Engenheiros & 140.538 & 10,7 & 142.686 & 11,6 & 130.619 & II,6 \\
\hline Arquitetos & 6.160 & 47,3 & 7.118 & 51,5 & 6.799 & 53,5 \\
\hline
\end{tabular}

Fonte: Brasil, 1990, 1993 e 1996.

agregado, de cerca de $31 \%$ em 1990, a presença feminina atinge 36\% em 1996. Entretanto, esse é um mundo de trabalho segmentado segundo os profissionais se enquadrem em dois tipos de carreira: os chamados profissionais do Direito, definidos como todos os funcionários vinculados ao poder público, aos quais é vetado o exercício da advocacia, e os demais advogados e consultores jurídicos que exercem de fato aquela atividade, estejam eles inseridos como profissionais liberais ou assalariados de sindicatos, empresas públicas ou privadas. Descendo às desagregações da RAIS no nível de grupo de base ${ }^{13}$, verificou-se o mesmo movimento em cada uma das carreiras isoladamente. Assim, as juízas e promotoras já representavam um quarto da categoria ${ }^{14}$ em 1996, as advogadas 39\% (eram 33\% em 1990), as procuradoras e consultoras jurídicas, 42\% (eram 38\% em 1990).

A seguir, procuramos traçar um breve panorama de cada uma dessas carreiras, destacando suas principais características e as transformações recentes pelas quais estão passando. É nesse contexto que se deve situar a ampliação da presença feminina entre esses profissionais.

13. Os grupos de base da Classificação Brasileira de Ocupações - $C B O$ - a que estamos nos referindo aqui são: |-2 | advogados, I-29 juristas não classificados sob outras epígrafes (procurador da Fazenda Nacional, procurador autárquico, procurador de empresa e consultor jurídico) e 2-13 membros superiores do Poder Judiciário.

14. Segundo a RAIS, a proporção de empregos femininos nesta carreira em 31//2/1990 era 19,8\%. O Censo Demográfico realizado em setembro/outubro de 1991, por sua vez, indicou exatamente a mesma proporção: 19,8\% dos juízes e promotores brasileiros eram do sexo feminino. No caso especial desta carreira, caracterizada por empregos públicos formais, ambas as fontes de dados apresentaram coincidência exata nas proporções. 
A Engenharia evoluiu em importância no Brasil à medida que as condições de desenvolvimento do próprio capitalismo assim o exigiram, como destaca Kawamura (1996). Assim, será entre 1930 e meados da década de 70 que a Engenharia vai se estabelecer como profissão, na esteira das mudanças básicas na organização da produção no país em direção à industrialização por substituição de importações - numa primeira fase, até 1945 -, à industrialização extensiva e à internacionalização do mercado interno, a seguir. Após a II Guerra Mundial, a atuação dos engenheiros passou a ser na indústria, identificando-se com as atividades tecnológicas e adaptando-as à produção.

Silva (1992) situa alguns pontos que poderiam explicar, historicamente, a masculinização das engenharias. Em primeiro lugar, no Brasil, as engenharias estiveram associadas no nascedouro a escolas militares ${ }^{15}$, e o acesso de civis a essas carreiras só ocorreu da metade do século XIX para frente. Assumir a modalidade militar implicava uma recusa formal à entrada de mulheres na profissão e, além disso, a Engenharia Militar significava também a preparação de homens para postos de comando como oficiais. Em segundo lugar, a característica de comando de equipes de trabalhadores permaneceu na Engenharia Civil, mesmo quando sua origem militar estava esquecida, tornando-se mais uma razão para afastar as mulheres da profissão. Com o crescimento das cidades e o desenvolvimento da industrialização, alarga-se o campo de trabalho para os engenheiros: são requisitados para planejamento e infra-estrutura urbana, planejamento, instalação e operação de indústrias de vários ramos e, a partir dos anos 50 - com a chegada do capital estrangeiro e o aumento da participação dos setores mais modernos na atividade industrial -, em atividades de racionalização da produção e de administração. Aquela autora ressalta que o local em que se desenvolvem os trabalhos de Engenharia influencia diretamente na presença feminina: nos relacionados à implantação de infra-estrutura, que se dão "a céu aberto", a presença de mulheres é rara, ao passo que ela é mais consistente naqueles trabalhos relacionados à industrialização, que ocorrem "intramuros".

Mesmo que a área da Engenharia continue sendo reduto dos homens, as taxas de participação feminina internas às especialidades das engenharias trazem uma surpresa: em algumas delas a presença da mulher já se faz sentir com mais vigor em 1996. É o caso da Engenharia de Organização e Métodos $^{16}$, na qual um quarto dos empregos são ocupados

15. Escola de Artilharia e Arquitetura Militar na Bahia (1696) e Academia Real Militar do Rio de Janeiro (|8| I).

16. Segundo a $\mathrm{CBO}$, "os trabalhadores deste grupo de base estudam e põem em prática métodos destinados à utilização eficiente, segura e econômica de pessoal, materiais e equipamentos... Suas funções consistem em: estudar, planejar e programar a organização dos processos de produção e as operações comerciais e administrativas e assessorar no que diz respeito aos métodos utilizados para esses fins; planejar, orientar e interpretar os estudos de tempos e movimentos; desenvolver métodos para a avaliação do trabalho fabril; assessorar no que concerne às medidas a serem adotadas para a segurança no trabalho; organizar e implantar métodos de controle da qualidade" (Brasil, 1994, p. 44). 
por mulheres, e da Engenharia Química (22\%). Ambas as especialidades são desenvolvidas no interior de indústrias, ou segundo a expressão de Silva (op. cit.), no espaço interno, "intramuros". Quanto à Engenharia Civil, à Agronomia e à Engenharia de Minas e Geologia - atividades "a céu aberto" -, a participação feminina nos empregos formais dessas especialidades gira entre 10\% e 14\%. Guetos de atuação ainda preferencialmente masculina permanecem as áreas da Mecânica e da Metalurgia: menos de 5\% dos postos de trabalho em ambas as especialidades são ocupados por mulheres ${ }^{17}$.

Como se verifica na tabela 13, a seguir, na qual são apresentadas algumas das características das profissionais analisadas neste texto, as engenheiras tendem a ser mais jovens do que seus colegas, reflexo claro do seu ingresso mais recente na carreira: enquanto 49\% dos engenheiros tinham, em 1996, 40 anos e mais, a proporção de mulheres na mesma faixa etária não ultrapassava 3 I\%. Também estudos realizados por Ballario (1997 e 1998) entre as mulheres que mantêm cadastro ativo no Conselho Regional de Engenharia, Arquitetura e Agronomia de São Paulo - CREA/SP -, salientam a juventude dessas profissionais, cuja idade média é 33 anos. Esse perfil se reflete diretamente no tempo de permanência nos empregos. Há uma porcentagem maior de engenheiros que mantêm o vínculo com seus empregos há dez anos e mais, quando comparada àquela das engenheiras, respectivamente $41 \%$ e $37 \%$.

A grande maioria dos engenheiros e engenheiras são empregados regulares, regidos pela CLT, com contratos por tempo indeterminado ( $90 \%$ deles e três quartos delas). Nessa carreira o diferencial de gênero no tocante ao vínculo de trabalho é a maior facilidade de ingresso das profissionais no serviço público: quase um quarto das engenheiras trabalham para o serviço público e apenas $9 \%$ dos engenheiros.

p porte das empresas não diferencia o sexo do profissional, ou seja, tanto os engenheiros como as engenheiras acham-se distribuídos em proporções semelhantes segundo o tamanho dos estabelecimentos onde trabalham: aproximadamente $22 \%$ em estabelecimentos de pequeno porte (até 99 empregados), 28\% em estabelecimentos médios (de 100 a 499 empregados) e entre $48 \%$ e $50 \%$ em grandes empresas (500 e mais empregados). A tendência para ambos os sexos, portanto, é trabalhar em empresas de grande porte.

Em termos de horas semanais trabalhadas, os dados indicam uma diferença influenciada, provavelmente, pela maior presença das engenheiras no serviço público. É mais expressiva entre elas (10\%) - do que entre eles (6\%) - a proporção dos que trabalham em meio período, até 30 horas por semana e das que trabalham entre 31 e 40 horas por semana. Nesta última situação encontravam-se $46 \%$ das engenheiras e $42 \%$ dos engenheiros. Em contrapartida, é mais freqüente entre os homens uma dedicação maior à vida profissional: $52 \%$ trabalham em período integral (de 41 a 44 horas semanais) enquanto apenas $44 \%$ das engenheiras o fazem.

17. Dados da RAIS levantados pelas autoras e que podem ser encontrados na versão integral deste texto. 
A principal diferenciação reside, entretanto, nos ganhos auferidos. Apenas $16 \%$ dos homens ganhavam até 10 salários mínimos, mas entre as mulheres a porcentagem encontrada foi 35\%. A comparação dos ganhos diferenciados entre engenheiras e engenheiros se confirma observando a faixa de rendimento mais elevada: apenas $31 \%$ delas ganham mais de 20 salários mínimos $^{18}$, mas 57\% deles se enquadravam nessa faixa em 1996.

Arquitetura, arquitetas e arquitetos

Segundo Durand ( 1989), o perfil do profissional de Arquitetura sofreu importante modificação a partir dos anos 70 e 80. Os homens de cultura - expressão que identificava as antigas gerações de arquitetos, com sólida formação humanística, artística e cultural, descendentes das elites do país - seriam substituídos por profissionais advindos das classes médias urbanas ${ }^{19}$, sem a bagagem cultural dos seus antecessores e que não possuíam as expectativas de futuro das gerações passadas. $\bigcirc$ próprio modo de trabalhar sofreria importantes alterações. Gradativamente iria ocorrer o abandono do padrão liberal de trabaIho (ateliês de projeto) em favor de maior burocratização, em razão do aumento do número de profissionais empregados em grandes e médias empresas do setor privado e maior exigência de especialização dos profissionais, o que redundaria, como conseqüência dessas modificações, na redefinição do paradigma da Arquitetura. Na esfera do ensino, assistiu-se a um processo de racionalização, privilegiando as características técnicas, incorporando a informática na elaboração de projetos e uma tendência à internacionalização de estilos. Os projetos individuais diferenciados pelo estilo arquitetônico ficaram restritos à alta burguesia, mercado cada vez menor, em razão do processo de concentração de renda que vinha se intensificando no país. Enquanto isso, proliferaram projetos destinados à construção de casas populares padronizadas (sistema Banco Nacional da Habitação - BNH) e à construção de imóveis padronizados de alto padrão para atender às grandes massas urbanas. Concomitantemente, firma-se no país um mercado para objetos de decoração de ambientes bastante segmentado, permitindo a convivência na comercialização, de um lado, de objetos de estilo mais requintados destinados às classes mais abastadas e de outro, de objetos destinados às classes médias urbanas, disseminados por periódicos e revistas de decoração. É nesse contexto que as mulheres passaram a engrossar as estatísticas da profissão: de um lado, as condições socioeconômicas e culturais proporcionaram maiores oportunidades de profissionalização, de inserção no mercado de trabalho como profissionais universitárias, assalariadas ou não e, de outro, um contingente expressivo de mulheres passou a buscar formação de nível superior. Supõe-se que essa escolha feminina pelo curso

18. Os estudos de Ballario citados indicam proporções aproximadas: entre as engenheiras, apenas $29 \%$ ganhavam mais de 20 salários mínimos mensais.

19. Lembre-se que naquelas décadas se iniciou o processo de ampliação de vagas em Arquitetura nas universidades e a abertura de outras tantas em instituições privadas de ensino superior, democratizando o acesso à profissão. 
de Arquitetura tenha, entre outras razões, a percepção da Arquitetura como ramo mais próximo à decoração e às artes do que a Engenharia.

A tendência do perfil etário das arquitetas (Tabela 13) se assemelha ao já comentado para as engenheiras e para as demais profissionais de nível universitário analisadas neste estudo: elas são mais jovens, quando comparadas aos arquitetos. Cerca de $60 \%$ deles têm mais de 40 anos e apenas $41 \%$ delas. Esse perfil, entretanto, parece incidir com menor intensidade do que no caso dos engenheiros no tempo de permanência no emprego, o que pode ser demonstrado pelas proporções encontradas na faixa de cinco anos e mais de casa: $65 \%$ dos arquitetos e $62 \%$ das arquitetas ali se classificavam.

Também para esses profissionais, a forma mais freqüente de vínculo com o trabalho é via CLT, por tempo indeterminado (60\% para ambos os sexos). Diferentemente da Engenharia, entretanto, o emprego no serviço público é igualmente relevante tanto para os homens como para as mulheres: $38 \%$ das arquitetas e 39\% dos arquitetos desempenham suas atividades profissionais em órgãos da administração pública direta e indireta, como servidores efetivos e não efetivos.

O tamanho do estabelecimento, novamente, não diferencia o emprego segundo o sexo do profissional. $\bigcirc$ mesmo se pode dizer a respeito do número de horas trabalhadas por semana, uma vez que $22 \%$ dos arquitetos e igual proporção das arquitetas trabalham até 30 horas por semana, $45 \%$ deles e $41 \%$ delas trabalham entre 31 e 40 horas e $33 \%$ dos homens e $36 \%$ das mulheres trabalham entre 4 I e 44 horas semanais. Na verdade, ocorre até uma ligeira inversão, com uma proporção ligeiramente maior de arquitetas trabalhando por um período mais longo do que os seus colegas.

Essa profissão, no entanto, apresenta uma peculiaridade em relação ao tipo de vínculo de trabalho. Segundo Ballario (op.cit.), o tipo de vínculo de trabalho mais comum entre os profissionais cadastrados no CREA/SP não é o de assalariados registrados, mas o de autônomos regulares. No caso específico das mulheres arquitetas, por exemplo, aquele estudo encontrou a seguinte distribuição: 28\% assalariadas registradas, 43\% autônomas regulares, 13\% empresárias e 10\% free-lancers.

Quanto aos níveis de remuneração, mais uma vez os homens levam vantagem sobre as mulheres: $72 \%$ deles ganham mais de 10 salários mínimos e apenas $67 \%$ delas. A desigualdade salarial fica mais evidente na faixa de mais alto rendimento: cerca de um terço dos arquitetos, mas apenas $25 \%$ das arquitetas ganham mais de 20 salários mínimos.

Medicina, médicas e médicos

Como dito anteriormente, vem aumentando a participação das mulheres nessa profissão: em 1996, 38\% do contingente de médicos brasileiros era do sexo feminino. Vale, entretanto, perguntar: há segregação feminina segundo as especialidades médicas?

Ao tentar responder a essa questão tomando como ângulo de análise o volume de 
emprego registrado pela RAIS, observa-se que para ambos os sexos, a maior concentração dos empregos (68\% dos médicos e 67\% das médicas) se encontra na ocupação "Médico em Geral" que, conforme explicita a Classificação Brasileira de Ocupações - CBO - congrega as atividades da Clínica Geral ${ }^{20}$. Segundo esse enfoque, portanto, não parece haver segregação sexual segundo as especialidades médicas, mas uma concentração - verificada para ambos os sexos - na Clínica Geral, observadas as ressalvas já tecidas a respeito das possíveis distorções provenientes da própria fonte dos dados ${ }^{21}$.

Conforme Esteves (1993), a Clínica Médica e suas variadas especialidades parece ser a área na qual as relações entre os sexos se desenrolam sem maiores constrangimentos. Ressalta que essa foi uma área conquistada gradativamente pelas mulheres. Atualmente a presença feminina nessa área é reconhecida pelos homens e também aceita pelas pacientes mulheres. $\bigcirc$ processo de avanço e consolidação da posição feminina na Clínica Médica foi acontecendo no tempo, como relatam os médicos mais antigos entrevistados por aquela autora: seus depoimentos indicam a relutância das clientes em serem atendidas por ginecologistas e obstetras do sexo feminino.

Por um outro ângulo, entretanto, pode-se detectar áreas médicas mais ou menos femininas. Ao analisar a proporção de mulheres dentro de cada especialidade médica, fica claro que a sua presença parece se impor em um maior leque de especialidades, ainda que os empregos, em números absolutos, sejam de pequena monta. As especialidades nas quais, em 1996, sua presença é mais marcante (acima de 50\% do conjunto de médicos daquela especialidade) são, em ordem de importância, a Medicina Sanitarista, a Pediatria, a Dermatologia, a Hemoterapia, a Patologia Clínica, a Nefrologia, a Endocrinologia, a Fisiatria e a Homeopatia.

Num patamar intermediário, ou seja, as especialidades médicas em que a participação feminina gira entre menos de $50 \%$ e 30\%, se situam, entre outras, a Ginecologia, a Obstetrícia, a Clínica Geral, a Psiquiatria. Na outra ponta, podem ainda ser consideradas especialidades de domínio masculino, a área de Perícias Médicas, a Cirurgia em geral, a Cardiologia, a Medicina Esportiva e a do Trabalho, a Medicina Legal, a Ortopedia e a Urologia. Neste grupo de especialidades a presença feminina não chega a atingir $30 \%$.

O volume total de emprego registrado pela RAIS 96 para ambos os sexos no país, na maioria das especialidades médicas, mostrou-se bastante pequeno ( 145.454 postos de

20. Atente-se que para esse resultado pode estar contribuindo uma característica própria dessa fonte de dados, como já comentamos anteriormente: a classificação de profissionais em categorias mais genéricas ou no residual "outros".

21. Esses dados vêm corroborar informações coletadas pela pesquisa Perfil dos Médicos do Brasil, realizada pela Fundação Osvaldo Cruz - Fiocruz -, pelo Ministério da Saúde e pelo Programa das Nações Unidas para o Desenvolvimento - PNUD -, a partir dos profissionais registrados nos órgãos de classe entre 1929 e 1993 (Fiocruz, 1996). Ela ressalta que apenas 10 entre 64 especialidades médicas congregam quase dois terços dos médicos brasileiros: Pediatria ( I 3,4\%), Ginecologia e Obstetrícia ( I I ,8\%), Medicina Interna (8\%), Cirurgia Geral (5,5\%), Anestesiologia (5,2\%), Cardiologia (4,8\%), Ortopedia e Traumatologia (3,7\%), Oftalmologia (3,6\%), Psiquiatria (3,3\%), Medicina Geral e Comunitária (2,6\%). 


\section{QUADRO 2}

REPRESENTATIVIDADE FEMININA NAS ESPECIALIDADES MÉDICAS

Alta representatividade (acima de 50\% em cada especialidade são mulheres): Medicina Sanitarista, Pediatria, Dermatologia, Hemoterapia, Patologia Clínica, Nefrologia, Endocrinologia, Fisiatria, Homeopatia

Média representatividade (entre 30\% e menos de 50\%): Radioterapia, Ginecologia, Pneumotisiologia, Obstetrícia, Clínica Geral, Proctologia, Angiologia, Psiquiatria, Neurologia, Anestesiologia, Otorrinolaringologia, Radiologia, Oftalmologia, Endoscopia

Baixa representatividade (menos de 30\%): Cirurgia, Cardiologia, Medicina Esportiva e do Trabalho, Medicina Legal, Ortopedia, Urologia

trabalho). Certamente aqui está pesando, além das dificuldades de classificação correta das ocupações, também o fato de um grande contingente desses profissionais manter outros tipos de vínculo de trabalho além do emprego com registro em carteira ou o vínculo formal estatutário no serviço público. De fato, estudo de Machado (1997) indicava para 1995 a existência de 350 mil postos de trabalho médico (públicos e privados). Detectou também que mais de $70 \%$ dos médicos exerciam atividades em consultório, o que ampliaria as chances de colocação desses profissionais, atingindo aproximadamente 500 mil postos de trabalho. Segundo os cálculos daquela autora, a média de atividades ou empregos por médico girava em torno de três.

Ainda segundo Esteves (1993), algumas representações das especialidades médicas poderiam estar influenciando as escolhas femininas na profissão. Assim, atribuir-se-ia aos homens áreas e especialidades em que é preciso ser mais agressivo e decidido, intervir de forma mais radical, como a Cirurgia, a Cardiologia, a Anestesiologia. Não por acaso os profissionais dessas áreas são os mais prestigiados e mais bem remunerados e, particularmente no caso dos cirurgiões, a representação social thes atribui um grande conhecimento da Medicina e uma habilidade peculiar: a arte das mãos. Quanto às mulheres, são associadas a especialidades ligadas às doenças crônicas, como Oncologia e Reumatologia, que exigem paciência e persistência ou a áreas assemelhadas ao seu papel no espaço privado: Pediatria, Ginecologia, Nutrição etc. Não por acaso, também são áreas nas quais há maior dificuldade de acesso a melhores níveis de remuneração e maior prestígio. Esses estereótipos sociais acompanhados de níveis inferiores de status e remuneração, entretanto, atingem também o homem que se dedica a essas especialidades. A mesma autora traz expressões reveladoras associadas, por exemplo à Pediatria, que na sua versão feminina atribui à médica pediatra o caráter de "a dona-de-casa da Medicina" e, na versão masculina, rotula o médico pediatra como "inspetor de fraldas".

A Medicina, porém, também é uma profissão em transformação. Segundo Machado, 
.... revolução tecnológica do final do século $X X$ tem provocado mudanças significativas nos saberes e nas práticas da profissão médica. A autonomia técnica, o poder de decisão, a relação médico-paciente, a tradicional hegemonia médica nas equipes de saúde, o domínio e conhecimento globalizante do corpo humano, bem como o prestígio e status quo dos médicos sofreram abalos importantes, alterando não só a dinâmica interna da profissão como e, especialmente, a nova visão social que a sociedade passa a produzir sobre os médicos em geral. (1997, p.30)

A institucionalização e a burocratização dos serviços médicos nos últimos tempos colocam em questão a autonomia médica e a própria representação da categoria como profissionais liberais. No primeiro caso, a decisão a respeito de honorários, consultas e cirurgias, tempo de trabalho, antes estabelecida no âmbito da relação médico-paciente, passou a ser intermediada por uma organização empresarial pública ou privada. Além disso, segundo a pesquisa Perfil dos Médicos do Brasil, entre 75\% e 90\% dos médicos declararam depender diretamente dos convênios com empresas de saúde, medicina de grupo, cooperativas médicas. A grande maioria atende essa clientela em seus consultórios particulares, que então deixam de ser a característica identificadora do profissional liberal. Não estranha, portanto, o fato de essa mesma pesquisa ter identificado um sentimento negativo da categoria em relação ao futuro profissional, refletindo o descontentamento e a falta de perspectivas. Na raiz desse sentimento acha-se a transformação da representação social que a classe fazia de si mesma. Ela não reside, segundo a mesma fonte, na multiplicidade das atividades simultâneas desempenhadas (em média três por médico), característica peculiar da dinâmica da inserção dos médicos no mercado de trabalho, mas na perda da autonomia descrita, referência do profissional liberal.

perfil etário das profissionais médicas tem a característica de ser mais jovem do que aquele dos seus colegas do sexo masculino (Tabela 13). Assim, têm menos de 40 anos $62 \%$ das médicas e apenas $42 \%$ dos médicos. Em termos do vínculo de trabalho, tanto os médicos como as médicas encontram-se praticamente divididos pela metade entre iniciativa privada e serviço público e deve-se ressaltar que a proporção de médicas e médicos no serviço público é praticamente a mesma: $50 \%$ e 48,5\%, respectivamente. $\bigcirc$ tempo de permanência nos empregos sinaliza para uma pequena diferença entre homens e mulheres, no sentido já esperado, uma vez que as médicas são mais jovens e estão adentrando a área profissional mais recentemente: enquanto $51 \%$ dos médicos estão em seus empregos há 5 anos e mais, a proporção de médicas com esse mesmo tempo de casa atinge 45\%. A grande maioria dos médicos de ambos os sexos (71\% deles e 73\% delas) trabalha em grandes estabelecimentos (500 empregados e mais). Recorde-se aqui que grande parte do cuidado médico à população se concentra em grandes hospitais públicos e privados e em empresas de medicina de grupo e convênios médicos ${ }^{22}$.

22 Ressalte-se mais uma vez que os registros da RAIS dão conta da existência de postos de trabalho formais declarados pelas empresas. Isso traz duas conseqüências. A primeira delas é que fica de fora da contagem parcela importante de médicos e médicas que desenvolvem suas atividades apenas e tão-somente como 
Em termos de horas semanais trabalhadas, até em razão da própria natureza do trabalho, a grande maioria de homens e de mulheres (cerca de 70\% para ambos os sexos) se localiza na faixa de até 30 horas por semana. Já quanto ao rendimento médio mensal, a diferenciação entre os dois sexos se faz presente. Metade dos médicos e 56\% das médicas auferem, em média, até dez salários mínimos por mês. Enquanto, porém, 16\% das médicas ganham até cinco salários mínimos, apenas 13\% dos médicos se encontram nessa faixa de remuneração. A diferenciação de ganhos fica ainda mais evidente na classe de rendimentos superior: 14\% dos médicos e 10\% das médicas ganham mais de 20 salários mínimos por mês.

Esse perfil é semelhante ao encontrado por Machado (1997), para quem são poucas as variações na inserção feminina na profissão. Segundo esse estudo, o contigente feminino trabalha um pouco menos em consultórios, faz menos plantão, estando ligeiramente mais inserido no mercado de trabalho por meio do emprego público e aufere rendimentos menores que seus colegas homens. Entretanto, elas têm o mesmo número de vínculos que os homens (média de três), desenvolvem as mesmas especialidades e trabalham o mesmo número de horas.

Direito, advogadas e advogados, Ministério Público

Elias (1989) afirma que para entender essas categorias profissionais, deve-se considerar a crise da Advocacia. Esta estaria se transformando de setor tradicional para o moderno, ou seja, estaria ocorrendo um gradativo esvaziamento do aspecto liberal da profissão, com a emergência de novas relações profissionais dependentes do monopólio dos grandes escritórios (ou bancas) e com o recrutamento de assalariados para empresas públicas e privadas. As bancas tenderiam a monopolizar serviços jurídicos, atraindo inclusive a clientela de pequenos escritórios de profissionais liberais. Recrutariam seus quadros entre estudantes estagiários, os quais, após a formatura, poderão vir a ser contratados como profissionais autônomos ou como sócios, recebendo porcentagem do movimento geral, ou pelo número de processos sob sua responsabilidade. A autora identifica, ainda, transformações na advocacia de empresas, as quais passariam a requisitar profissionais mais especializados e capazes de trabalho interdisciplinar, o que, de forma geral, não vem se coadunando com a formação liberal e generalista enfatizada nos cursos de Direito.

Nessa passagem, estaria ocorrendo perda de prestígio profissional em favor de especialistas de outras áreas (economistas e engenheiros, por exemplo), perda relativa de acesso ao poder político antes privativo dos bacharéis, uma certa perda de autonomia no exercício profissional, uma vez que cada vez maiores contingentes de advogados passam a

pessoas físicas (autônomos com ou sem registro) em seus próprios consultórios particulares. A segunda é a possibilidade da dupla contagem de profissionais, uma vez que um médico, por exemplo, pode ser registrado em mais de um estabelecimento. 
TABELA 13

ENGENHARIA, ARQUITETURA, MEDICINA

PRINCIPAIS CARACTERÍSTICAS DO EMPREGO - BRASIL, 1996

\begin{tabular}{|c|c|c|c|c|c|c|}
\hline \multirow[b]{2}{*}{ CARACTERÍSTICAS DO EMPREGO } & \multicolumn{6}{|c|}{ OCUPAÇÕES } \\
\hline & \multicolumn{2}{|c|}{$\begin{array}{l}\text { Engenheiros } \\
\text { Homens Mulheres }\end{array}$} & \multicolumn{2}{|c|}{\begin{tabular}{|c|} 
Arquitetos \\
Homens Mulheres \\
\end{tabular}} & \multicolumn{2}{|c|}{$\begin{array}{c}\text { Médicos } \\
\text { Homens Mulheres }\end{array}$} \\
\hline \multicolumn{7}{|l|}{ IDADE } \\
\hline Até 29 anos & $\mid 4,7$ & 25,1 & 8,1 & 15,6 & 7 & 13 \\
\hline De 30 a 39 anos & 36,4 & 43,9 & 33,1 & 43,7 & 35,1 & 48,7 \\
\hline 40 anos e mais & 48,7 & 31 & 58,6 & 40,6 & 57,5 & 38,3 \\
\hline Total & 100 & 100 & 100 & 100 & 100 & 100 \\
\hline \multicolumn{7}{|l|}{ VÍNCULO DE TRABALHO } \\
\hline CLT por tempo indeterminado & 89,9 & 74,3 & 59,1 & 60,3 & 48,9 & 47,1 \\
\hline Servidor público & 9,2 & 23,9 & 39,4 & 37,9 & 48,5 & 50,1 \\
\hline CLT por tempo determinado & 0,5 & ।,4 & 0,5 & 0,7 & 1,3 & 1,3 \\
\hline Outros tipos de vínculos & 0,4 & 0,4 & 1 & 1,1 & 1,2 & 1,4 \\
\hline \multicolumn{7}{|l|}{$\begin{array}{l}\text { TEMPO DE PERMANÊNCIA } \\
\text { NO EMPREGO }\end{array}$} \\
\hline Até 3 anos & 33,9 & 35,9 & 26,2 & 29,1 & 34,8 & 39,6 \\
\hline Mais de 3 a menos de 5 anos & 8,2 & 8,8 & 9,2 & 9 & 13,7 & 15,2 \\
\hline De 5 a menos de 10 anos & 16,7 & 18,7 & 18,3 & 20,7 & 21 & 22,6 \\
\hline 10 anos e mais & $4 I, 1$ & 36,6 & 46,2 & $4 I, I$ & 30,5 & 22,6 \\
\hline Total & 100 & 100 & 100 & 100 & 100 & 100 \\
\hline \multicolumn{7}{|l|}{ TAMANHO DO ESTABELECIMENTO } \\
\hline Até 99 empregados & 22,9 & 22,4 & 23,9 & 27,8 & 10,3 & 11,7 \\
\hline De 100 a 499 empregados & 28,4 & 27 & 27,3 & 24,3 & 18,4 & 15,3 \\
\hline 500 e mais & 48,6 & 50,6 & 48,9 & 47,8 & 71,3 & 72,9 \\
\hline Total & 100 & 100 & 100 & 100 & 100 & 100 \\
\hline \multicolumn{7}{|l|}{ HORAS SEMANAIS TRABALHADAS } \\
\hline Até 30 horas & 6,2 & 10,4 & 22,1 & 22,5 & 69,7 & 71,3 \\
\hline De 31 a 40 horas & 41,6 & 45,7 & 45 & 41,5 & 20 & 20 \\
\hline De 41 a 44 horas & 52,2 & 43,9 & 32,9 & 36 & 10,3 & 8,7 \\
\hline Total & 100 & 100 & 100 & 100 & 100 & 100 \\
\hline \multicolumn{7}{|l|}{ RENDIMENTO MÉDIO MENSAL } \\
\hline Até IOSM & 16,2 & 34,8 & 28,4 & 32,9 & 50,3 & 56 \\
\hline mais de 10 a 20 SM & 26,9 & 33,9 & 37,8 & 42,1 & 35 & 33,5 \\
\hline Mais de 20 SM & 56,8 & 31,3 & 33,8 & 25 & $|4|$, & 9,7 \\
\hline Total & 100 & 100 & 100 & 100 & 100 & 100 \\
\hline
\end{tabular}

Fonte: Brasil, 1996. 
ser assalariados de empresas e de grandes escritórios, além de uma certa fragmentação profissional com o surgimento de especializações (Direito Agrário, Empresarial, Financeiro, por exemplo). Se considerarmos, ao mesmo tempo, a grande expansão da presença feminina na advocacia e o espaço naturalmente restrito para sua colocação em postos de trabalho no Ministério Público, podemos deduzir que a grande maioria das formandas acaba se direcionando para o exercício efetivo da advocacia em empresas e grandes escritórios. E é justamente nesses espaços onde elas estarão expostas aos maiores níveis de competição e discriminação. Por um lado, ao conciliarem suas funções de profissional com as de mãe, esposa e mulher, reduzem consideravelmente suas possibilidades de sucesso e ascensão na carreira, pois a advocacia é considerada uma profissão full-time. Por outro, ficam expostas a discriminações, tanto por parte dos clientes que preferem advogados atuando em sua defesa, como por parte de colegas de profissão na disputa por postos hierárquica e financeiramente mais vantajosos e, ainda, discriminações relativas a áreas de trabalho: enquanto as áreas comercial e tributária seriam reservadas para os homens, o direito de família parece ser considerado mais adequado à atuação da mulher (Junqueira, 1998a).

Diante de um cenário de intensa competição, discriminação e de dificuldades no mercado de trabalho, a magistratura tem-se constituído como uma importante opção profissional para os jovens, particularmente para os do sexo feminino. Exige, entretanto, grande dedicação de esforço e tempo, desde o período de estudos necessário para prestar concurso público até o exercício da profissão propriamente dito, que se dá inicialmente em comarcas do interior. Num tal contexto, a vida familiar e conjugal das magistradas mais jovens tende a sofrer sérios abalos, seja porque o cônjuge deve assumir também o papel de mãe e dona-de-casa ou ainda porque a nova posição da mulher - inclusos prestígio e remuneração - desafia a posição tradicional do homem no contexto familiar. Apesar da tensão inerente ao seu exercício - uma vez que lida com conflitos - e ao grande volume de trabalho, a magistratura se caracteriza por empregos que gozam de estabilidade profissional e financeira, permitem flexibilidade de horário e são atrativos em razão do poder atribuído a essas funções (Junqueira, 1998).

Para evidenciar melhor as características da inserção feminina nas ocupações escoIhidas nesta área do Direito, optamos por analisá-las conjuntamente, nas dimensões perfil etário, vínculo de trabalho, tamanho do estabelecimento e tempo de permanência no emprego, horas mensais trabalhadas e rendimento médio mensal. As informações sobre essas ocupações são apresentadas na tabela 14 e sumariadas a seguir.

\section{Perfil etário}

O grupo de profissionais da área jurídica - assim como as engenheiras, arquitetas e médicas - é mais jovem do que seus colegas do outro sexo. E nesse grupo, as advogadas são ainda mais jovens. Senão vejamos: 
TABELA 14

DIREITO - PRINCIPAIS CARACTERÍSTICAS DO EMPREGO

BRASIL, 1996

\begin{tabular}{|c|c|c|c|c|c|c|}
\hline \multirow{2}{*}{$\begin{array}{c}\text { CARACTERÍSTICAS } \\
\text { DO EMPREGO }\end{array}$} & \multicolumn{6}{|c|}{ OCUPAÇÕES } \\
\hline & \multicolumn{2}{|c|}{ Advogados } & \multicolumn{2}{|c|}{$\begin{array}{c}\text { Promotores, procuradores } \\
\text { consultores jurídicos } \\
\text { Homens Mulheres }\end{array}$} & \multicolumn{2}{|c|}{\begin{tabular}{|c} 
Juízes \\
Homens Mulheres
\end{tabular}} \\
\hline \multicolumn{7}{|c|}{ | } \\
\hline Até 29 anos & 13 & 24 & 10,9 & 16,2 & 7,2 & 14,3 \\
\hline De 30 a 39 anos & 31 & 37,9 & 34,1 & 38,1 & 28,2 & 37,1 \\
\hline 40 anos e mais & 55,7 & 38,1 & 54,8 & 45,7 & 64,5 & 48,7 \\
\hline Total & 100 & 100 & 100 & 100 & 100 & 100 \\
\hline \multicolumn{7}{|l|}{ VÍNCULO DE TRABALHO } \\
\hline CLT por tempo indeterminado & 79,6 & 77,4 & 11,3 & 7,6 & 0,8 & 2 \\
\hline Servidor público & 19,6 & 21,7 & 87,4 & 91 & 97,3 & 96,2 \\
\hline CLT por tempo determinado & 0,2 & 0,4 & 0,2 & 0,1 & 1,2 & 1,2 \\
\hline Outros tipos de vínculos & 0,5 & 0,4 & $\mathrm{I}, \mathrm{I}$ & 1,3 & 0,8 & 0,6 \\
\hline Total & 100 & 100 & 100 & 100 & 100 & 100 \\
\hline \multicolumn{7}{|l|}{ TEMPO DE PERMANÊNCIA NO } \\
\hline \multicolumn{7}{|l|}{ EMPREGO } \\
\hline Até 3 anos & 32,3 & 37,8 & 17,9 & 19,9 & 25,9 & 28,9 \\
\hline Mais de 3 a menos de 5 anos & 11,3 & 10,8 & 12,8 & 15,8 & 15,2 & 18,8 \\
\hline De 5 a menos de 10 anos & 19 & 19,1 & 24,7 & 28,8 & 23,2 & 25,8 \\
\hline 10 anos e mais & 37,2 & 32,2 & 44,2 & 35,4 & 35,5 & 26,4 \\
\hline Total & 100 & 100 & 100 & 100 & 100 & 100 \\
\hline \multicolumn{7}{|l|}{ TAMANHODO } \\
\hline \multicolumn{7}{|l|}{ ESTABELECIMENTO } \\
\hline Até 99 empregados & 32,4 & 31,7 & 8,6 & 7 & 0,9 & 2,2 \\
\hline De 100 a 499 empregados & 28,9 & 25,4 & 26,5 & 26 & 9 & 7,1 \\
\hline 500 e mais & 38,6 & 42,9 & 64,9 & 67,1 & 90 & 90,7 \\
\hline Total & 100 & 100 & 100 & 100 & 100 & 100 \\
\hline \multicolumn{7}{|l|}{ HORASSEMANAIS TRABALHADAS } \\
\hline Até 30 horas & 25,9 & 26 & 27,8 & 24,2 & 28,7 & 30,7 \\
\hline De 31 a 40 horas & 38 & $4 I, 1$ & 62,3 & 69,1 & 66,2 & 64,4 \\
\hline De 4 I a 44 horas & 35,7 & 32,8 & 9,7 & 6,7 & 5,2 & 4,7 \\
\hline Total & 100 & 100 & 100 & 100 & 100 & 100 \\
\hline \multicolumn{7}{|l|}{ RENDIMENTO MÉDIO MENSAL } \\
\hline Até IOSM & 28,7 & 30,6 & 20,8 & 25,3 & 3 & 3,8 \\
\hline Mais de 10 a 20 SM & 27,9 & 33,5 & 19,1 & 20,8 & 3,8 & 2,1 \\
\hline Mais de 20 SM & 43,3 & 35,9 & 60,1 & 53,9 & 93,2 & 94 \\
\hline Total & 100 & 100 & 100 & 100 & 100 & 100 \\
\hline
\end{tabular}

Fonte: Brasil, 1996. 
a. 14\% das juízas e 7\% dos juízes têm até 29 anos; nessa mesma faixa estão 16\% das procuradoras e promotoras e apenas I I\% dos seus colegas; um quarto das advogadas tem menos de 30 anos e apenas 13\% dos advogados;

b. Nas três carreiras, a faixa de idade que concentra um maior número de mulheres é a que vai até os 40 anos;

\section{Vínculo de trabalho, tamanho do estabelecimento e tempo de permanência no emprego}

Como seria de se esperar, o serviço público é o local de trabalho da quase totalidade dos juízes de ambos os sexos. A maioria dos procuradores, promotores e consultores jurídicos - homens e mulheres - também presta seus serviços para o aparelho estatal, em repartições de tamanho médio e grande. É ligeiramente maior, entretanto, a proporção de mulheres nessas ocupações vinculadas ao setor público: $91 \%$ e $87 \%$ dos homens. Em contrapartida, I $1 \%$ dos homens e apenas 7,6\% das mulheres são contratados pela CLT por tempo indeterminado, provavelmente, tratando-se aqui dos consultores jurídicos que advogam para empresas privadas.

No caso dos advogados, essas características divergem das anteriormente comentadas: pouco mais de três quartos das advogadas e $80 \%$ dos advogados trabalham para o setor privado, com contratos por tempo indeterminado. É apenas ligeiramente maior entre as advogadas o emprego no setor público: cerca de 22\% delas e $20 \%$ deles são servidores públicos efetivos e não efetivos. Os profissionais da advocacia se distribuem de forma equilibrada entre estabelecimentos pequenos (cerca de um terço para ambos os sexos) e médios (cerca de um quarto para ambos os sexos). As advogadas estão ligeiramente mais concentradas em grandes escritórios e empresas - com mais de 500 empregados - (43\%) quando comparadas aos seus colegas (39\%).

O tempo de permanência no emprego tem relação direta com a idade dos profissionais. É de se esperar, portanto, que os homens estejam em seus empregos há mais tempo do que as mulheres, tendência que se verifica nas três categorias aqui analisadas.

\section{Horas semanais trabalhadas e rendimento médio mensal}

A maioria dos juízes e dos procuradores, promotores e consultores jurídicos, sem diferenciação por sexo (cerca de dois terços dos homens e das mulheres), trabalham pelo período de 31 a 40 horas por semana. $\bigcirc$ outro terço desses profissionais desenvolve atividades em meio período, até 30 horas por semana, sem grandes diferenças segundo o sexo. Vale notar, apenas: - entre os procuradores, promotores e consultores jurídicos do sexo masculino, 28\% trabalham até 30 horas por semana, enquanto somente $24 \%$ das suas colegas se encontram na mesma situação; - por sua vez, uma proporção assemelhada de juízas (31\%) trabalha em regime de meio período, quando comparada à 
dos homens (29\%). Como lembra Junqueira (1998, p. |47), os magistrados gozam da liberdade de realizar parte de suas tarefas em casa, até por falta de condições infraestruturais dos cartórios, onde são obrigados a atender sem ter à disposição computadores próprios e livros de doutrina e jurisprudência. Os juízes elaboram as sentenças e os despachos mais complexos em suas residências, indo aos cartórios apenas quatro vezes por semana, na parte da tarde. Para a mulher, especialmente, essa flexibilidade facilita em muito a conciliação dos seus deveres de juíza com os de mãe e esposa.

Os advogados do sexo masculino encontram-se divididos quanto ao número de horas semanais trabalhadas: um quarto deles trabalha em regime de meio período (até 30 horas), 38\% entre 31 e 40 horas e $36 \%$ de 41 a 44 horas. Entre as advogadas é ligeiramente mais expressiva a jornada de trabalho entre 31 e 40 horas.

A remuneração dos juízes e juízas apresenta-se, comparativamente às outras duas carreiras, mais equânime: cerca de $94 \%$ desses profissionais, de ambos os sexos, ganham mais de 20 salários mínimos por mês, em média. Diferenciais de remuneração segundo o sexo ficam mais explícitos entre os procuradores, promotores e consultores jurídicos e entre os advogados. Na primeira categoria, 75\% das mulheres e $79 \%$ dos homens auferem mais de dez salários mínimos por mês, mas a diferença mais significativa se situa na classe superior de rendimentos, mais de 20 salários mínimos. Aqui se enquadram 54\% das promotoras, procuradoras e consultoras jurídicas e $60 \%$ dos seus colegas do outro sexo.

Junto aos advogados repete-se a mesma tendência: 69\% das mulheres e 71\% dos homens ganham mais de dez mínimos por mês, mas apenas 36\% das advogadas e 43\% dos advogados recebem mais de 20 mínimos mensais pelos serviços prestados.

\section{CONSIDERAÇÕES FINAIS}

Este artigo teve como objetivo analisar em profundidade, com base em múltiplas fontes, uma realidade que já vinha sendo constatada em trabalhos anteriores: a participação das mulheres no mercado de trabalho caracteriza-se no Brasil por ter dois pólos opostos de atividade. $O$ primeiro abriga as ocupações de má qualidade quanto aos níveis de rendimento, formalização das relações e proteção no trabalho. $\bigcirc$ outro, as boas ocupações, caracterizadas por níveis mais elevados de formalização, de rendimentos e proteção. Do primeiro pólo, selecionamos como objeto de análise o emprego doméstico. Dados dos Censos Demográficos e das PNADs para os anos 90, até 1997, comprovaram algumas marcas da precariedade dessa ocupação, como os baixos níveis de rendimento e de formalização da categoria, assim como as longas jornadas de trabalho. Contudo, revelaram também alguns sinais promissores de mudança ao longo do tempo, como a ampliação do registro em carteira e uma melhora salarial, sobretudo para algumas subcategorias, como as diaristas, e nas regiões mais desenvolvidas do país. Mostraram 
também a ocorrência de um relativo envelhecimento dessa categoria ocupacional, tradicionalmente formada por mulheres muito jovens, em virtude de um provável deslocamento das mais jovens e mais escolarizadas para outras ocupações.

No pólo oposto, dentre as boas ocupações, foram analisadas a Arquitetura, a Engenharia, a Medicina e o Direito, comparando a inserção feminina à masculina, principalmente pelos dados da RAIS e até 1996. A análise mostrou que o ingresso das mulheres nesses nichos ocupacionais teria se dado como resultado da convergência de vários fatores. De um lado, uma intensa transformação cultural, a partir do final dos anos 60 e, sobretudo, nos 70, na esteira dos movimentos sociais e políticos dessa década, impulsionando as mulheres para as universidades, em busca de um projeto de vida profissional, e não apenas doméstico. A expansão das universidades públicas e, principalmente, privadas, na mesma época, foi ao encontro desse anseio feminino. De outro lado, a racionalização e as transformações pelas quais passaram essas profissões, como descrevemos neste texto, abriram novas possibilidades para as mulheres que se formaram nessas carreiras, ampliando o leque profissional feminino para além dos guetos tradicionais, como o Magistério e a Enfermagem. Tanto a Medicina, como a Arquitetura e a Advocacia vêm passando por processos de especialização e assalariamento, em detrimento da antiga autonomia profissional. As representações sociais construídas, tanto pela sociedade como pelas próprias categorias, também estão se modificando, particularmente no que diz respeito ao seu perfil liberal, o que repercute no nível de prestígio e status atribuído a esses profissionais.

Os dados revelaram que o perfil dessas profissionais se diferencia daquele dos seus colegas do sexo masculino, apenas por serem mais jovens. Elas, assim como eles, estão distribuídas de forma assemelhada entre os setores público e privado (exceto no caso dos engenheiros) e trabalham número de horas bastante aproximado por semana. No entanto, apesar de estarem adentrando novos e promissores espaços de trabalho, nem por isso essas mulheres deixam de estar sujeitas a padrões diferenciados por gênero, entre os quais a discriminação salarial é apenas o mais evidente: em todas as profissões analisadas a tônica é o menor patamar de ganhos femininos quando comparado ao masculino. Por outro lado, essas profissionais, ainda que não ganhem como os homens, têm rendimentos infinitamente superiores aos da ocupação do outro pólo analisado, as trabaIhadoras domésticas. Ironicamente, é no trabalho das empregadas domésticas que as profissionais freqüentemente irão se apoiar para poder se dedicar à própria carreira. Este é o elo que une os dois pólos analisados.

\section{REFERÊNCIAS BIBLIOGRÁFICAS}

ALMEIDA, M. S. K. de. Entre nós mulheres, elas as patroas e elas as empregadas. In: ALMEIDA, M. S. K. et al. Colcha de Retalhos. estudos sobre a família no Brasil. São Paulo: Brasiliense, 1982. p. 185-93. 
BALLARIO, C. (coord.) O Homem e o mercado de trabalho. São Paulo: CREA/Conselho Regional de Engenharia, Arquitetura e Agronomia do Estado de São Paulo, 1998. . (coord.) A Mulher e o mercado de trabalho. São Paulo: CREA/Conselho Regional de Engenharia, Arquitetura e Agronomia do Estado de São Paulo, 1997.

BONELLI, M. G., DONATONI, S. Os Estudos sobre profissões nas Ciências Sociais Brasileiras. B/B. Rio de Janeiro: ANPOCS, n. 4I, p. 109-42, I ${ }^{\circ}$ sem. 1996.

BRASIL. Ministério do Trabalho. CBO: Classificação Brasileira de Ocupações. Brasília, 1994. BRASIL. Ministério do Trabalho. Rais. Brasília, 1990. Brasília, 1993. Brasília, 1996.

BRITES, J. Cinderela domesticada: um estudo sobre saberes femininos que circulam entre empregadas domésticas e suas empregadoras, jun. 1997 (Relatório Final apresentado ao VII Concurso de Dotações para Pesquisa sobre Mulheres e Relações de Gênero - II Programa Relações de Gênero na Sociedade Brasileira.)

BRUSCHINI, C. Fazendo as perguntas certas: como tornar visível a contribuição econômica das mulheres para a sociedade? In: ABRAMO, L., ABREU, A. R. P. (orgs.). Gênero e trabalho na sociologia latino-americana. São Paulo; Rio de Janeiro: ALAST, 1998. p.277-94.

. Gênero e trabalho feminino no Brasil: novas conquistas ou persistência da discriminação; 1985 a 1995. São Paulo, 1998a. (Texto apresentado no Seminário TrabaIho e Gênero: mudanças, permanências e desafios, organizado pela ABEP/Associação Brasileira de Estudos Populacionais e NEPO/Núcleo de Estudos de População. UNICAMP.)

Mulher, casa e familia: cotidiano nas camadas médias paulistanas. São Paulo: Fundação Carlos Chagas; Vértice/Revista dos Tribunais, 1990.

Trabalho das mulheres no Brasil: continuidades e mudanças no período 1985 1995. São Paulo: Fundação Carlos Chagas. 1998b. (Textos FCC, 17)

. Uso de abordagens quantitativas em pesquisas sobre relações de gênero. In: BRUSCHINI, C., COSTA, A. O. (orgs.). Uma questão de gênero. Rio de Janeiro: Rosa dos Tempos; São Paulo: Fundação Carlos Chagas, 1992. p. 289-309.

CENTRO FEMINISTADEESTUDOSEASSESSORIA. Guia dos direitos da mulher. Brasilia: CFEMEA, 1994.

DURAND, J. C. Arte, privilégio e distinção: artes plásticas, arquitetura e classe dirigente no Brasil, 1855 - 1985. São Paulo: Editora Perspectiva; EDUSP, 1989. (Coleção Estudos) 
ELIAS, R. Mulher e advocacia: elementos de ideologia e trabalho. Rio de Janeiro, 1989. Dissert. (mestr.) IUPERJ.

EMPREGADO doméstico: acesso ao regime de FGTS... /OB. Legislação Trabalhista e Previdenciária, v. 24, n.8, p. I, fev. 2000.

ESTEVES, F. M. M. Modernidade em questão: a inserção das mulheres na Medicina, uma profissão tradicionalmente exercida por homens. Rio de Janeiro, 1993. Dissert. (mestr.) IUPERJ.

FIBGE. Censo demográfico. Rio de Janeiro, 1970.

Rio de Janeiro, |991.

. Rio de Janeiro, 1995.

Rio de Janeiro, 1997.

Censo demográfico, domicílios e famílias. Rio de Janeiro, 1991a.

Censo demográfico mão-de-obra. Rio de Janeiro, 1980.

Rio de Janeiro, 199/b.

PNAD. Rio de Janeiro, 199 IC.

. Rio de Janeiro, 1995a.

Rio de Janeiro, 1997a.

FIOCRUZ et al. Perfil dos médicos no Brasil. Rio de Janeiro, 1996. v. I (Brasil e Grandes regiões).

GOGNA, M. Empleadas domésticas en Buenos Aires. In: CHANEY, E. M., CASTRO, M. G. (orgs.). Muchacha, cachifa, criada, empleada, empregadinha, sirvienta y... más nada: trabajadoras del hogar en América Latina y el Caribe. Venezuela: Nueva Sociedad, 1993. p. 82-97.

GRAHAM, S. L. Sirvientas y amos en Rio de Janeiro en la década de 1870: percepciones de la casa y de la calle. In: CHANEY, E. M., CASTRO, M. G. (orgs.). Muchacha, cachifa, criada, empleada, empregadinha, sirvienta y... más nada: trabajadoras del hogar en América Latina y el Caribe. Venezuela: Editora Nueva Sociedad, 1993. p. 67-78.

JUNQUEIRA, E. A Mulher juíza e a juíza mulher. In: BRUSCHINI, C., HOLLANDA, H. B. (orgs.). Horizontes Plurais. novos estudos de gênero no Brasil. São Paulo: Editora 34; Fundação Carlos Chagas, 1998. p. 135-62.

A Profissionalização da mulher na advocacia. 1998a. (Projeto de pesquisa apresentado no Seminário do VIII Concurso de Dotações para Pesquisa sobre Mulhe- 
res e Relações de Gênero, organizado pela Fundação Carlos Chagas, dentro do III Programa Relações de Gênero na Sociedade Brasileira, São Paulo.)

KAWAMURA, L. Engenheiro, trabalho e ideologia. In: BONELLI, M. G., DONATONI, S. Os Estudos sobre profissões nas ciências sociais brasileiras. B/B. Rio de Janeiro: ANPOCS, n. 4I, p. 109-42, Isem. 1996.

LE MONDE. Les inegalités hommes. femmes s'accentuent de nouveau. Paris, 25 fev. 1998.

LIBERATO, V. C. A Dinâmica do serviço doméstico remunerado nos anos noventa no Brasil. Belo Horizonte: CEDEPLAR/UFMG, 1999. mimeo.

MACHADO, M. H. (coord.). Os Médicos no Brasil, o retrato de uma realidade. Rio de Janeiro: FIOCRUZ, 1997.

MATOS, M. I. S. Porta Adentro: criados de servir em São Paulo de 1890 a I 930. In: BRUSCHINI, C., SORJ, B. (orgs.). Novos olhares. mulheres e relações de gênero no Brasil. São Paulo: Marco Zero; Fundação Carlos Chagas, 1994. p. 193-212.

MELO, H. P. De criadas a trabalhadoras. Estudos Feministas. Rio de Janeiro: IFCS/UFRJ, v. 6, n.2, p.323-57, 1998.

SAFFIOTI, H. I. B. Emprego doméstico e capitalismo. Petrópolis: Vozes, 1978.

SAMARA, E. M. Mão-de-obra feminina, oportunidades e mercado de trabalho no Brasil do século XIX. In: SAMARA, E. M. (org.). As ldéias e os números do gênero: Argentina, Brasil e Chile no século XIX. São Paulo: Hucitec; Cedhal/USP; Fundação VITAE, 1997. p. $2|-6|$.

SILVA, E. B. Fazendo gênero na cozinha: tecnologias e práticas. Revista Latinoamericana de Estudios del Trabajo. v. 4, n. 7, p. 29-53, 1998.

SILVA, M. T. A Engenheira, um estudo empírico da divisão sexual do trabalho. São Paulo, 1992. Dissert. (mestr.) EAESP/FGV - Teoria do Comportamento Organizacional. 